\title{
Macrobioerosion of dead branching Porites, 4 and 6 years after coral mass mortality
}

\author{
M. Carreiro-Silva ${ }^{1, *}$, T. R. McClanahan ${ }^{2}$ \\ ${ }^{1}$ Center of IMAR of the University of Azores, Department of Oceanography and Fisheries \& LarSyS - Associated Laboratory, \\ Horta 9901-862, Portugal \\ ${ }^{2}$ Marine Programs, Wildlife Conservation Society, Bronx, New York 10460, USA
}

\begin{abstract}
Internal bioerosion by macroborers (polychaetes, sipunculans, bivalves, and sponges) was investigated in dead Porites branches collected from 8 coral reefs along the Kenyan coast, 4 and 6 yr after the 1998 mass mortality of corals. Levels of nutrients, benthic cover, and numbers of grazing and invertebrate-eating fish and sea urchins were measured and evaluated for their influence on macrobioerosion. The macroboring community composition was influenced by the grazer composition on each reef; worms were the major macroboring agent where sea urchin biomass was high, and sponges were the dominant agent where herbivorous fish biomass was high. Bivalves accounted for a small proportion of the internal bioerosion and were not measurably influenced by consumers or water quality. The total macrobioerosion rates in Porites branches ranged from $534 \pm 70$ to $1134 \pm 44 \mathrm{~g} \mathrm{CaCO}_{3} \mathrm{~m}^{-2}$ (4 yr after the coral death) and $837 \pm 111$ to $2149 \pm 314 \mathrm{~g} \mathrm{CaCO}_{3} \mathrm{~m}^{-2}$ (6 yr after the coral death). The macrobioerosion rates were linearly and positively correlated with chlorophyll a concentrations ( $\mathrm{chl} a$ ) in the water column 4 and $6 \mathrm{yr}$ after the coral death. Sponge boring rates were also positively correlated to chl a $6 \mathrm{yr}$ after coral death but not after the initial $4 \mathrm{yr}$. Consequently, the macrobioerosion rates responded to nutrient status, but the community of borers changed with the dominant grazers, which in turn were influenced by fisheries management.
\end{abstract}

KEY WORDS: Calcium carbonate Climate disturbance $\cdot$ Kenya $\cdot$ Marine protected areas Monitoring $\cdot$ Pollution $\cdot$ Reef framework $\cdot$ Thermal anomaly

\section{INTRODUCTION}

Climate effects, fishing, and land-based pollution are expected to interact and lead to global changes in the ecology and calcium carbonate balance of coral reefs (Glynn 1997, McClanahan 2002, Fabricius 2005, Hughes et al. 2007). Excess nutrients in reef waters have been associated with increased cover of algae and non-calcified invertebrates, particularly in overfished areas where herbivory is reduced (Smith et al. 1981, Birkeland 1988, McClanahan et al. 1999, Lapointe et al. 2004). In turn, coral mortality related both to El Niño or Southern Oscillation events and global warming may interact with excess nutrients and reduced herbivory by increasing the amount of dead coral substrate available for colonization by these organisms, potentially leading to shifts from calcifying to non-calcifying communities (McClanahan 2002, Hughes et al. 2007). In degraded reefs, the calcium carbonate budget is reduced by the simultaneous decrease in live coral cover, and therefore the capacity for reef accretion, and the increase in the bioerosion of reef frameworks by boring micro- (cyanobacteria, algae, and fungi) and macroorganisms (sponges, bivalves, polychaetes, and sipunculans) and grazing echinoids (Glynn 1997, Carreiro-Silva \& McClanahan 2001, Tribollet \& Golubic 2011). 
Many endolithic macroorganisms are filter feeders that can benefit from eutrophication (Smith et al. 1981). In fact, eutrophication has been linked to increased macrobioerosion in numerous studies of the fossil record (e.g. Hallock \& Schlager 1986, Hallock 1988) and in modern coral reefs (e.g. Rose \& Risk 1985, Edinger et al. 2000, Holmes et al. 2000). Hallock (1988) suggested that nutrient availability might have increased bioerosion rates in the past and might have been responsible for the demise or drowning of reefs or carbonate platforms in the geological record. Studies of modern reefs have documented increased abundance of macroborers in areas of enhanced nutrient availability in different geographic locations, e.g. the Caribbean (Rose \& Risk 1985, Holmes 2000, Ward-Paige et al. 2005), Eastern Pacific (Fonseca et al. 2006), Great Barrier Reef (GBR), Australia (Sammarco \& Risk 1990, Risk et al. 1995, Tribollet et al. 2002, Tribollet \& Golubic 2005, Le Grand \& Fabricius 2011), and Asia (Scott \& Cope 1986, Edinger et al. 2000, Holmes et al. 2000). Based on this evidence, bioerosion rates have been proposed as bioindicators of changing water quality (Holmes et al. 2000, Risk et al. 2001, Cooper et al. 2009, Le Grand \& Fabricius 2011).

Grazers, such as sea urchins and parrotfish, also influence the development of macroborer communities, macrobioerosion rates (Sammarco et al. 1987, Kiene \& Hutchings 1992, 1994), and epilithic algal cover (Chazottes et al. 2002), potentially affecting the responses of macroborers to changes in water quality. For example, Kiene \& Hutchings (1992) suggested that the rate of boring may be underestimated when erosion by grazers is high. Additionally, Chazottes et al. (2002), in studies of bioerosion processes at Reunion Island (Indian Ocean), recorded low macrobioerosion associated with high cover of macroalgae and crustose coralline algae where reefs were receiving high nutrient inputs. Consequently, benthic cover and grazers are expected to interact and influence the response of macroborers to eutrophication, with implications for using macroborers as indicators of changing water quality.

The detection of relationships between nutrient enrichment and increased bioerosion may be influenced by the type of substrate and the time that the substrate has been exposed to bioerosion processes (LeGrand \& Fabricius 2011). Most of the above studies were conducted on dead coral blocks that were exposed for $<3$ yr. This length of time may be insufficient for evaluating the entire succession of macroborers, possibly leading to misinterpretations of the importance of slower colonizers, such as sponges and bivalves, which are leading bioeroders on many coral reefs (Kiene \& Hutchings 1994, Chazottes et al. 1995, Le Grand \& Fabricius 2011). Additionally, despite the high cover of branching corals on many coral reefs, most studies have used coral blocks made of massive Porites for estimating bioerosion rates over time (Kiene \& Hutchings 1992, Chazottes et al. 1995, Tribollet et al. 2002), while fewer studies have used branching corals (Musso 1992, Lescinsky 2004, Lescinsky et al. 2008).

A mass die-off of corals in Kenya resulting from a temperature anomaly in 1998 (McClanahan et al. 2001) provided the opportunity to conduct a longterm 'natural experiment' aimed at understanding the biotic and abiotic factors that influence bioerosion rates. These natural experiments are good alternatives to traditional experimental block studies and avoid the common practice of killing corals (Lescinsky 2004). We investigated variations in the macrobioerosion of branching Porites 4 and $6 \mathrm{yr}$ after their death on 8 coral reefs that differed in their nutrient and fishing levels. The reefs differed in their nearness to shore, adjacent human population numbers, and their fisheries management, which influenced the numbers of sea urchins and fish and the benthic community structure.

Previous studies have focused on the effects of particular combinations of biotic and abiotic factors, such as eutrophication, sedimentation, number of grazers, and epilithic cover, on macrobioerosion (Kiene \& Hutchings 1992, Chazottes et al. 1995, Tribollet et al. 2002, Tribollet \& Golubic 2005). The present study is the first to simultaneously record several environmental and biotic parameters and the macroboring community influence on bioerosion. Consequently, the objectives of our study were (1) to estimate the rate of internal bioerosion by macroborers in branching Porites after the 1998 mass coral mortality event in Kenya, (2) to identify the environmental and ecological variables responsible for the variation in the macroboring community and rates of bioerosion, and (3) to test the suitability of macroborers as bioindicators of water quality.

\section{MATERIALS AND METHODS}

\section{Study sites}

Macrobioerosion processes were studied on 8 coral reefs along the Kenyan coast: 4 reefs in marine protected areas or fisheries closure areas, 2 heavilyfished reefs, and 2 marine reserves that were exposed 
to various levels of pollution and fishing and with varying numbers of herbivorous fishes and sea urchins (Fig. 1). Fisheries closures included (1) 3 fringing reef parks, the Malindi, Watamu, and Mombasa Marine National Parks (MNP), and (2) 1 offshore patch reef park, the Kisite MNP. Malindi MNP has received increasing sediment loads and nutrients from the Sabaki River associated with land use that has promoted soil loss for the past 50 yr (Dunne 1979, Fleitmann et al. 2007). The Watamu and Mombasa MNPs lack the river sediment problem but receive run-off from local creeks and groundwater. In contrast, the Kisite Marine Park in southern Kenya is at a sufficient distance away from the coast and river discharge and can be considered as a control for the expected nutrient enrichment effects in the other MNPs.

The fished locations included Diani and Kanamai fringing reefs. The marine reserves included Ras Iwatine fringing reef and Mpunguti offshore patch reef, which experience moderate but gear-restricted fishing. The Diani, Kanamai, and Ras Iwatine reefs are located close to urban areas, whereas Mpunguti reef is remote and is not subjected to any form of pollution. The grazer community in fisheries closure areas is dominated by herbivorous fishes, while it is dominated by sea urchins on fished reefs due to loss of fish predators (McClanahan \& Shafir 1990).

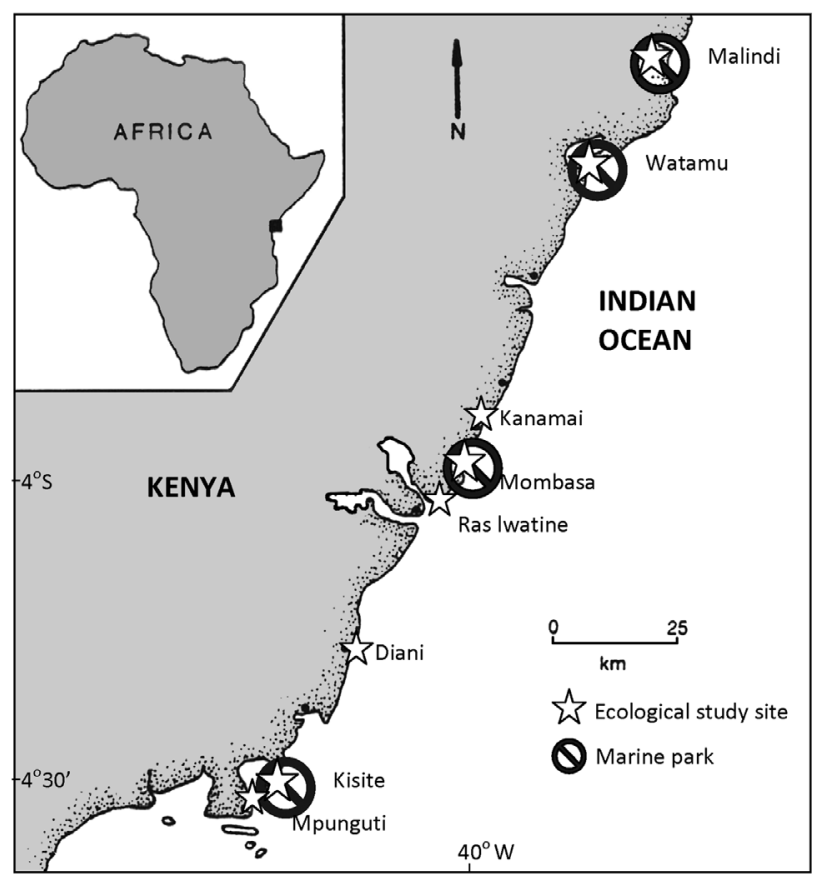

Fig. 1. Studied reefs along Kenya's coast. Sites included 4 marine national parks (Malindi, Watamu, Mombasa, and Kisite), 2 fished marine reserves (Ras Iwatine and Mpunguti), and 2 unprotected reefs (Kanamai and Diani)
On each reef, sampling occurred at 2 permanently marked sites $(\sim 30 \times 30 \mathrm{~m})$ in shallow $(<2 \mathrm{~m}$ depth at low tide) back-reef environments. The reefs were distributed along $\sim 450 \mathrm{~km}$ of the coastline and located 100 to $1000 \mathrm{~m}$ from shore (McClanahan \& Arthur 2001). More detailed descriptions of these locations are reported by Obura et al. (2000).

\section{Physicochemical data collection}

The oceanographic conditions in East African coastal waters are influenced by 2 distinct seasons: the northeast monsoon (October to March) and southeast monsoon (April to September). The southeast monsoon is characterized by high cloud cover, rainfall, river discharge, terrestrial runoff, and wind energy and decreased temperatures and light. These conditions are reversed during the northeast monsoon. These climatic phenomena ultimately affect the physical, chemical, and biological oceanographic processes (McClanahan 1988). Therefore, physicochemical data are reported for these 2 different seasons.

The physicochemical variables measured at 16 sites (2 at each of the 8 studied reefs) included nitrogen availability (as nitrate, nitrite, and ammonia concentrations), phosphorus availability (as orthophosphate concentration), chlorophyll a (chl a, a proxy for planktonic productivity), total particulate matter (TPM), and particulate organic matter (POM) concentrations in the water column, temperature, and water flow (Table 1). Each site was surveyed 14 times, 12 wk apart, between September 2002 and August 2005. Water samples were collected close to the reef surface using Nalgene bottles previously washed with a solution of $0.1 \mathrm{~N} \mathrm{HCl}$. Up to 3 water samples were collected using 11 bottles for nitrate, nitrite, ammonia, and phosphate analyses. In addition, 5 replicate water samples were collected using 31 dark jars for chl $a$, total suspended matter, and particulate organic matter measurements. The water temperature was measured with a water temperature logger (Hobo Temp, Onset), which recorded hourly values at each reef site over a period of 2 to 3 yr. Current speed was estimated using clod cards deployed at each of the study sites, following descriptions by McClanahan et al. (2005).

Nutrient concentrations were measured no more than $4 \mathrm{~h}$ after collection with a Hach DR/2500 spectrophotometer using the cadmium reduction method for nitrate and the ascorbic acid method for phosphorus (Parsons et al. 1984). Total particulate matter 
Table 1. Concentrations (mean \pm SD) of total particulate matter (TPM), particulate organic matter (POM), chlorophyll $a$, temperature, and current speed in unfished reefs (marine national parks, MNPs) and fished reefs. Variables are reported for 2 different seasons: northeast monsoon (NEM) and southeast monsoon (SEM) $\mathrm{n}=84$ per reef for nutrient concentrations; $\mathrm{n}=90 \mathrm{for}$ total particulate matter, particulate organic matter, and chlorophyll $a_{i} \mathrm{n}=10$ for temperature and current speed; nd: no data available

\begin{tabular}{|c|c|c|c|c|c|c|c|c|}
\hline \multirow[t]{2}{*}{ Reef } & \multicolumn{2}{|c|}{ Nitrate + nitrite $(\mu \mathrm{M})$} & \multicolumn{2}{|c|}{ Ammonia $(\mu \mathrm{M})$} & \multicolumn{2}{|c|}{ Phosphate $(\mu \mathrm{M})$} & \multicolumn{2}{|c|}{ TPM $\left(\mathrm{mg} \mathrm{l}^{-1}\right)$} \\
\hline & NEM & SEM & NEM & SEM & NEM & SEM & NEM & SEM \\
\hline \multicolumn{9}{|c|}{ Unfished reefs (MNPs) } \\
\hline Malindi & $0.32 \pm 0.16$ & $0.25 \pm 0.08$ & $2.65 \pm 1.40$ & $3.60 \pm 0.77$ & $0.5 \pm 0.1$ & $0.75 \pm 0.27$ & $17.3 \pm 3.29$ & $13.4 \pm 2.28$ \\
\hline Watamu & $0.28 \pm 0.08$ & $0.32 \pm 0.08$ & $3.24 \pm 0.50$ & $1.75 \pm 0.92$ & $0.42 \pm 0.18$ & $0.53 \pm 0.28$ & $15.1 \pm 2.57$ & $13.3 \pm 4.42$ \\
\hline Mombasa & $0.25 \pm 0.08$ & $0.39 \pm 0.11$ & $3.79 \pm 0.73$ & $1.66 \pm 0.98$ & $0.70 \pm 0.35$ & $0.37 \pm 0.14$ & $16.7 \pm 3.14$ & $13.4 \pm 5.04$ \\
\hline Kisite & $0.24 \pm 0.07$ & $0.42 \pm 0.09$ & $3.13 \pm 0.71$ & $2.87 \pm 1.32$ & $0.40 \pm 0.21$ & $0.62 \pm 0.31$ & $15.3 \pm 2.04$ & $12.9 \pm 2.10$ \\
\hline \multicolumn{9}{|l|}{ Fished reefs } \\
\hline Ras Iwatine & $0.23 \pm 0.06$ & $0.29 \pm 0.08$ & $3.75 \pm 0.83$ & $2.29 \pm 1.47$ & $0.57 \pm 0.20$ & $0.80 \pm 0.46$ & $15.2 \pm 3.37$ & $12.7 \pm 4.14$ \\
\hline Mpunguti & $0.24 \pm 0.09$ & $0.27 \pm 0.15$ & $3.24 \pm 0.42$ & $2.35 \pm 1.18$ & $0.37 \pm 0.11$ & $0.44 \pm 0.28$ & $17.0 \pm 2.26$ & $12.5 \pm 2.54$ \\
\hline Kanamai & $0.25 \pm 0.02$ & $0.33 \pm 0.13$ & $3.24 \pm 1.02$ & $1.92 \pm 0.82$ & $0.66 \pm 0.36$ & $0.80 \pm 0.19$ & $15.7 \pm 2.02$ & $12.5 \pm 3.86$ \\
\hline Diani & $0.21 \pm 0.02$ & $0.30 \pm 0.09$ & $3.04 \pm 0.69$ & $2.08 \pm 0.92$ & $0.42 \pm 0.15$ & $0.47 \pm 0.31$ & $16.1 \pm 2.21$ & $13.1 \pm 3.91$ \\
\hline
\end{tabular}

was measured by filtering 31 of seawater onto preweighed Whatman GF/F filters $(0.45 \mu \mathrm{m}$ pore size), which were subsequently oven-dried $\left(70^{\circ} \mathrm{C}, 24 \mathrm{~h}\right)$ and weighed using a Mettler M3 balance (accuracy $\pm 1 \mu \mathrm{g})$. The difference in weight was equivalent to the suspended particulate material (organic and inorganic matter $>0.45 \mu \mathrm{m}$ in diameter). These filters were combusted at 450 to $500^{\circ} \mathrm{C}$ in a muffle furnace for $24 \mathrm{~h}$, cooled, and reweighed. The difference in weight was equivalent to the particulate organic matter (POM). Duplicate 21 seawater samples were filtered on $2.5 \mathrm{~cm}$ GF/F filters and frozen until chl a determination. Chl a was extracted by soaking filters in $90 \%$ acetone overnight at $4{ }^{\circ} \mathrm{C}$ and measured with a spectrofluorometer according to Parsons et al. (1984).

\section{Benthic substrate cover}

Sessile benthic communities were studied using the line-intercept method with 12 to 18 haphazardly placed $10 \mathrm{~m}$ line transects per site. Each site was sampled by a trained observer once a year between 2002 and 2005. The cover of benthic macrobiota under segments of the line $>3 \mathrm{~cm}$ in length was classified into 9 categories (hard coral, soft coral, algal turf, coralline algae, the calcareous algae Halimeda, fleshy algae, seagrass, sand, and sponge), and their lengths were measured to the nearest centimeter (McClanahan \& Shafir 1990). The topographic complexity of the reef was estimated by pressing the $10 \mathrm{~m}$ line along the contour of the reef, then measuring the straight-line distance that the line traveled, and dividing this result by $10 \mathrm{~m}$ (Risk 1972).

\section{Sea-urchin biomass}

Sea urchins were identified to species and counted in 9 to 12 haphazardly placed $10 \mathrm{~m}^{2}$ circular plots per site during daytime. The wet weight (WW) of each species was estimated from length-weight correlations for individual species (McClanahan \& Shafir 1990). The total sea urchin WW was estimated by summing the WWs of each species.

\section{Fish biomass}

Biomass of fish belonging to the family Scaridae (parrotfish) were visually estimated by a trained observer along two $5 \mathrm{~m} \times 100 \mathrm{~m}$ belt transects per site (McClanahan \& Kaunda-Arara 1996). Only fish belonging to this family were considered because they are the primary consumers of endolithic algae (Bruggemann et al. 1996). WW was quantified by estimating fish length divided into $10 \mathrm{~cm}$ size intervals. No individuals $<3 \mathrm{~cm}$ in length were recorded. WWs were estimated from length-weight correlations established from measurements of common species in this family (McClanahan \& Kaunda-Arara 1996).

\section{Coral skeletal sampling}

Six coral branches, $\sim 15$ to $20 \mathrm{~cm}$ in length, were collected from 6 dead branching (digitate) Porites coral colonies (e.g. Porites cylindrica, P. rus, or $P$. palmata) at each reef site (1 branch per colony). This genus is highly susceptible to bleaching, and nearly all individuals were killed in April 1998 by the warm 
Table 1 (continued)

\begin{tabular}{|c|c|c|c|c|c|c|c|}
\hline \multicolumn{2}{|c|}{$\mathrm{POM}\left(\mathrm{mg} \mathrm{l}^{-1}\right)$} & \multicolumn{2}{|c|}{ Chlorophyll a $\left(\mu \mathrm{g} \mathrm{l}^{-1}\right)$} & \multicolumn{2}{|c|}{ Temperature $\left({ }^{\circ} \mathrm{C}\right)$} & \multicolumn{2}{|c|}{ Current speed $\left(\mathrm{m} \mathrm{s}^{-1}\right)$} \\
\hline NEM & SEM & NEM & SEM & NEM & SEM & NEM & SEM \\
\hline $3.88 \pm 1.52$ & $1.90 \pm 0.61$ & $0.18 \pm 0.12$ & $0.44 \pm 0.32$ & $27.3 \pm 0.77$ & $26.0 \pm 1.47$ & $6.70 \pm 2.56$ & $8.88 \pm 1.54$ \\
\hline $3.05 \pm 0.55$ & $2.91 \pm 0.65$ & $0.20 \pm 0.09$ & $0.45 \pm 0.48$ & $27.5 \pm 0.72$ & $26.8 \pm 1.48$ & $7.95 \pm 2.18$ & $8.16 \pm 0.31$ \\
\hline $3.04 \pm 0.81$ & $2.83 \pm 1.67$ & $0.20 \pm 0.10$ & $0.36 \pm 0.19$ & $27.1 \pm 0.87$ & $26.9 \pm 1.57$ & $8.44 \pm 1.70$ & $7.72 \pm 1.81$ \\
\hline $2.50 \pm 0.31$ & $2.70 \pm 0.21$ & $0.15 \pm 0.08$ & $0.26 \pm 0.08$ & $27.4 \pm 0.83$ & $26.6 \pm 1.72$ & $9.45 \pm 2.90$ & $6.33 \pm 1.22$ \\
\hline $2.87 \pm 0.74$ & $2.46 \pm 1.11$ & $0.25 \pm 0.16$ & $0.42 \pm 0.24$ & $28.0 \pm 0.74$ & $29.5 \pm 0.68$ & $7.18 \pm 2.21$ & $7.67 \pm 0.98$ \\
\hline $3.11 \pm 0.63$ & $2.48 \pm 1.12$ & $0.18 \pm 0.12$ & $0.28 \pm 0.12$ & nd & nd & $7.74 \pm 0.48$ & $7.74 \pm 1.10$ \\
\hline $4.03 \pm 1.77$ & $2.62 \pm 0.87$ & $0.15 \pm 0.08$ & $0.44 \pm 0.26$ & $27.9 \pm 0.95$ & $27.4 \pm 1.80$ & $5.66 \pm 3.78$ & $4.93 \pm 1.40$ \\
\hline $3.11 \pm 0.96$ & $2.60 \pm 0.81$ & $0.23 \pm 0.15$ & $0.34 \pm 0.27$ & $27.9 \pm 0.73$ & $27.0 \pm 1.69$ & $9.63 \pm 4.08$ & $7.51 \pm 1.54$ \\
\hline
\end{tabular}

water temperature anomaly (McClanahan et al. 2001). In addition, the same number of samples of live branching Porites was also collected from Kanamai reef with the objective of determining if corals were bioeroded prior to their death; these samples act as a 'control' for our bioerosion estimates.

Coral sampling was undertaken at frequently visited and permanently marked monitoring sites, which made it possible to estimate the month that the coral colonies used in the present study died. Although it is possible that we may have missed some coral colonies that were so heavily eroded that they disappeared, potentially underestimating bioerosion rates, the majority of dead branching Porites colonies in the study sites still maintained their structural integrity. Moreover, we selected coral colonies with the same state of preservation (color and degree of encrustation by epilithic organisms) to further ensure that the corals studied were exposed to bioerosion for the same length of time, and we avoided corals that might have died prior to or after the bleaching event.

In September 2002 and 2004, dead coral branches that matched these criteria were haphazardly collected at a depth of 0.5 to $2 \mathrm{~m}$ during low tide. The estimated exposure time of these corals to colonization by bioeroders was 3.75 and 5.75 yr respectively (herein referred as 4 and 6 yr exposure). After collection, coral samples were immediately fixed in a buffered solution of $5 \%$ formaldehyde and seawater.

\section{Rates of bioerosion}

Three randomly located cross-sectional discs 1.5 to $4 \mathrm{~cm}$ in diameter and 0.7 to $1 \mathrm{~cm}$ thick were cut from coral branches (1 disk close to the base, 1 in the middle, and 1 close to the apex of the branch) using a diamond-blade rock saw. Boring organisms were removed while cutting the discs and were preserved in alcohol for subsequent taxonomic identification. Each disc was bleached to remove organics, soaked overnight in freshwater, and oven dried. Disc surfaces were scanned with a high-resolution flat-bed scanner, and the images were stored on a computer. The shape, size, and character of each borehole were used to identify boreholes made by individual groups of borers (worms, bivalves, and sponges; Fig. 2), as described by a number of investigators (Sammarco et al. 1987, Sammarco \& Risk 1990, Perry 1998). The program ImageJ (developed by the National Institute of Health [NIH], http://rsb.info.nih.gov/ij/) was employed to measure the total area of the disc and the surface areas of empty bioeroder cavities (Chazottes et al. 2002). The percentage of bioerosion per coral disc volume was converted to the mass of calcium carbonate removed by borers by multiplying the percentage of volume removed by the skeletal density of Porites $\left(1.3 \pm 0.15 \mathrm{~g} \mathrm{~cm}^{-3} ; \mathrm{S}\right.$. Mwachireya pers. comm.). The bulk skeletal density was determined from live coral branches of Porites cylindrica and P. rus collected on the Mombasa and Malindi MNPs ( $\mathrm{n}=5$ per reef) using the buoyant weight method (Bucher et al. 1998). Previous studies have reported lower coral skeletal density on nutrified nearshore reefs in comparison with offshore reefs (Sammarco \& Risk 1990, Edinger et al. 2000). For this reason, the coral skeletal density measurements used in the present study were taken from corals in reefs experiencing intermediate levels of nutrients and should therefore represent average estimates of coral skeletal density in Kenya. 

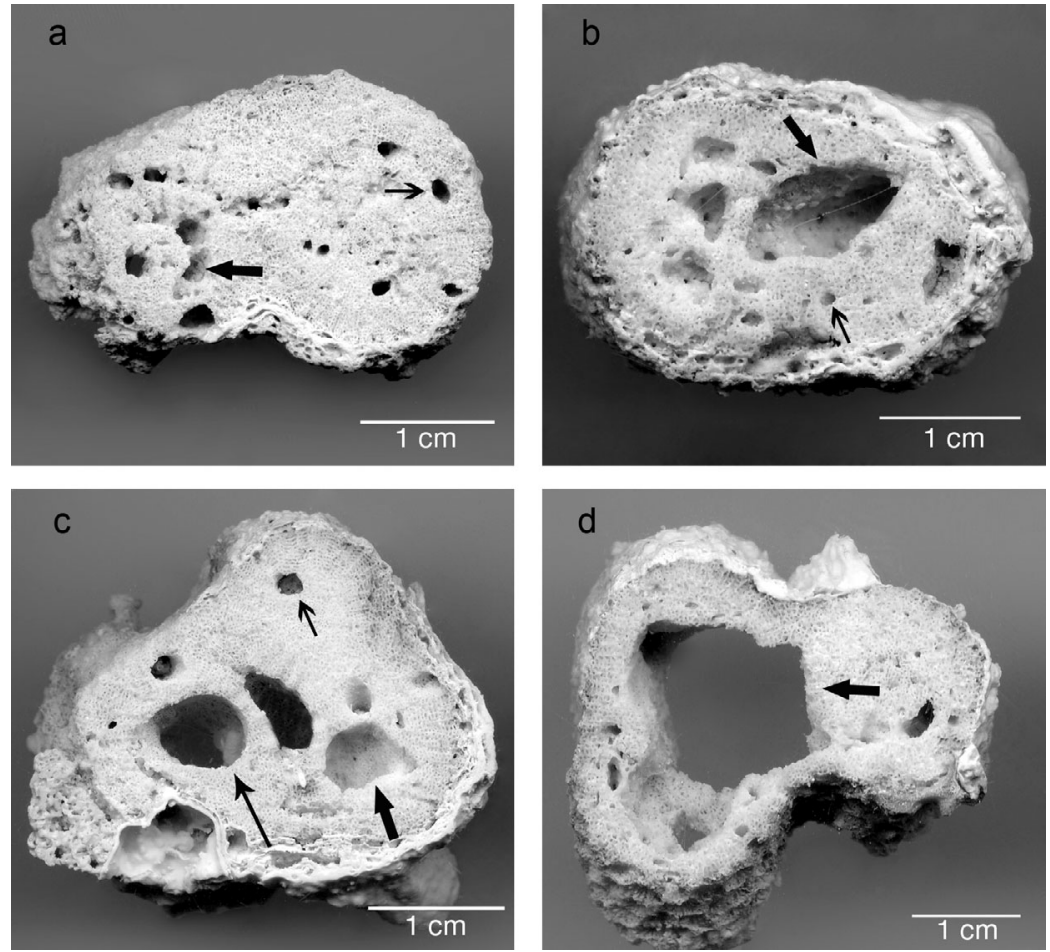

Fig. 2. Scanned branching Porites discs $(\mathrm{a}, \mathrm{b}) 4 \mathrm{yr}$ and $(\mathrm{c}, \mathrm{d}) 6 \mathrm{yr}$ after coral death. Examples from (a) Diani reef exhibiting boreholes produced by worms (narrow arrow) and sponges (wide arrow), (b) Malindi MNP with abundant boreholes produced by worms (narrow arrow) and sponges (wide arrow), (c) Kisite MNP showing boreholes produced by bivalves (long narrow arrow), sponges (wide arrow) and worms (short narrow arrow), and (d) heavily bioeroded sample from Watamu MNP, showing a large sponge borehole

Values were extrapolated from the coral discs and expressed as $\mathrm{kg}$ of removed $\mathrm{CaCO}_{3}$ per $\mathrm{m}^{2}$ of the surface area exposed (surface of all sides of the coral discs) to bioerosion per year $\left(\mathrm{kg} \mathrm{m}^{-2} \mathrm{yr}^{-1}\right)$. The cumulative rates were also quantified $\left(\mathrm{kg}\right.$ per $\mathrm{m}^{2}$ of surface area of coral discs after 4 and 6 yr of exposure). The proportional or relative contribution of each agent (worms, bivalves, and sponges) to bioerosion was expressed as a percentage of the total area bored.

\section{Statistical analyses}

A mixed model nested analysis of variance (ANOVA) was used to test for differences in inorganic nutrient concentrations, chl $a$, TPM, POM, temperature, and water flow among reefs and seasons (northeast monsoon and southeast monsoon) (mixed procedure; SAS Institute, 2004). Reefs and seasons were treated as fixed effects, whereas sites within reefs were treated as random effects in the model. Similarly, another mixed model ANOVA was used to test for differences in bioerosion rates among reefs and time ( 4 and 6 yr exposure) and to examine the variation in bioerosion rates between sites within a reef and among samples within each reef and site (mixed procedure; SAS Institute 2004). Reefs and seasons were fixed effects, whereas sites within reefs and coral branches within reef sites (inter-colony variation) were random effects. The residual variance corresponded to the variation among replicate discs within a coral branch (intra-colony variation).

Differences in the proportional contributions of different macroorganisms (sponges, bivalves, and worms) to macrobioerosion were tested with a nested ANOVA using the generalized linear mixed model 'Proc GLIMMIX' procedure of SAS (SAS Institute 2004, Littell et al. 2006) for proportion data. Percentages were logit-transformed to linearize the data, and models were fit to the data with residual pseudolikelihood. This model procedure assumed a pseudo-binomial error distribution because the data were recorded on a scale from 0 to 1 and had a logit-link function (SAS Institute 2004). The fixed and random effects in the model were as described above.

Fixed effects in the model were tested using the approximate $F$-tests of this procedure, and the random effect was tested with the variance component approach (Littell et al. 2006). The percentage of variation explained by each of the nested factors relative to the total variation was estimated by dividing the variance component of the nested factor by the total variance (sites within reefs + samples within sites and reefs + residual variance). The least squares differences test (LSD test; Sokal \& Rohlf 1995) was applied to perform post-hoc means comparisons for significant effects.

Cluster analyses were conducted to classify the studied reefs in relation to physicochemical and ecological variables (Ward's method, JMP software; Sall \& Lehman 1996). The physicochemical variables included nutrient concentrations, TPM, POM, chl $a_{\text {, }}$ temperature, and current speed. The ecological variables encompassed substrate cover data (live and dead coral, sponges, algae turfs, coralline algae, and macrophytes) and sea urchin and parrotfish biomass. The Ward method estimates the contribution of the 
variables to each cluster by computing the squared distance between each cluster's (class) center of gravity and the overall center of gravity (the origin) (Sall \& Lehman 1996).

Pearson's correlation coefficients were used to determine the relation between bioerosion rates and environmental variables indicative of eutrophication (chl $a$, total particulate matter, and particulate organic matter), as well as the relation between the relative contribution of each agent to macrobioerosion and substrate cover (live coral, sponges, algae turfs, calcareous algae Halimeda, coralline algae, and macrophytes) and the biomass of parrotfishes and sea urchins. The relations between bioerosion rates and environmental variables were also investigated with linear regression analysis (JMP software; Sall \& Lehman 1996).

Canonical correspondence analysis (CCA) was used to evaluate the influence of the type of management (fished vs. unfished), herbivore composition (sea-urchins and parrotfishes biomass), and water quality variables (TPM, POM, and chl a) on macroborer relative abundances and bioerosion rates. Each quantitative predictor variable was re- presented by a vector on the CCA plot, with the vector's length showing its relative importance for the composition of macroboring communities and bioerosion rates, while the location of a reef or response variable on the plot indicates its environmental preferences (ter Braak \& Verdonschot 1995). CCA was performed with Canoco version 4.5 software (Wageningen).

\section{RESULTS}

\section{Characterization of study sites}

\section{Physicochemical variables}

Nutrient concentrations on the studied reefs were strongly influenced by season, as indicated by a significant effect of season or a significant interaction between reefs and seasons for the measured parameters, except for phosphate concentration and seawater temperature (Tables $1 \& 2$ ). Among these, chl a showed the strongest seasonal variability for all reefs studied, with minimum values during the northeast

Table 2. Nested ANOVA of inorganic nutrients, chlorophyll $a$, total particulate matter, and particulate organic matter concentrations, temperature, and current speed on different reefs and in different seasons (northeast [NEM] and southeast monsoon [SEM]). Least-squares differences pair-wise test (LSD) on mean differences among reefs within each season. Means sharing the same letter are not statistically different. For random effects, the variance components are reported, while for fixed effects, the F-ratios and their probabilities are reported. df: ordinary least-squares degrees of freedom

\begin{tabular}{|c|c|c|c|c|c|c|c|c|}
\hline \multirow{2}{*}{ Variable } & \multirow[t]{2}{*}{ Effect } & \multirow[t]{2}{*}{$\mathrm{df}$} & \multirow{2}{*}{$\begin{array}{c}\text { Variance } \\
\text { component }\end{array}$} & \multirow[t]{2}{*}{$F$} & \multirow[t]{2}{*}{$\mathrm{p}$} & \multicolumn{3}{|c|}{ Pair-wise differences (LSD test) } \\
\hline & & & & & & Reef & NEM & SEM \\
\hline \multirow[t]{2}{*}{ Nitrate + Nitrite } & & & & & & Malindi & $\mathrm{a}$ & $\mathrm{a}, \mathrm{d}$ \\
\hline & & & & & & Watamu & a & $\mathrm{a}, \mathrm{b}$ \\
\hline Reefs & Fixed & 7 & & 1.16 & 0.3324 & Mombasa & $\mathrm{a}$ & $\mathrm{b}, \mathrm{c}$ \\
\hline Seasons & Fixed & 1 & & 13.22 & 0.0005 & Kisite & $\mathrm{a}$ & $\mathrm{b}, \mathrm{d}$ \\
\hline Reefs $\times$ Seasons & Fixed & 7 & & 1.97 & 0.0601 & Ras Iwatine & $\mathrm{a}$ & $\mathrm{a}, \mathrm{c}$ \\
\hline Site (Reef) & Random & & 0.001 & & & Mpunguti & $\mathrm{a}$ & $\mathrm{a}$ \\
\hline \multirow[t]{2}{*}{ Residual } & Random & & 0.008 & & & Kanamai & $\mathrm{a}$ & $a, b$ \\
\hline & & & & & & Diani & $\mathrm{a}$ & $\mathrm{a}, \mathrm{c}$ \\
\hline \multirow[t]{2}{*}{ Ammonia } & & & & & & Malindi & $\mathrm{b}, \mathrm{c}$ & $\mathrm{a}$ \\
\hline & & & & & & Watamu & $\mathrm{a}, \mathrm{c}$ & $\mathrm{b}, \mathrm{c}$ \\
\hline Reefs & Fixed & 7 & & 0.75 & 0.6320 & Mombasa & $\mathrm{a}$ & $\mathrm{C}$ \\
\hline Seasons & Fixed & 1 & & 20.88 & $<0.0001$ & Kisite & $\mathrm{a}, \mathrm{c}$ & $a, b$ \\
\hline Reefs $\times$ Seasons & Fixed & 7 & & 3.03 & 0.0071 & Ras Iwatine & $\mathrm{a}, \mathrm{c}$ & $\mathrm{b}, \mathrm{c}$ \\
\hline Site (Reef) & Random & & 0 & & & Mpunguti & $\mathrm{a}, \mathrm{c}$ & $\mathrm{b}, \mathrm{c}$ \\
\hline \multirow[t]{2}{*}{ Residual } & Random & & 0.886 & & & Kanamai & $\mathrm{a}, \mathrm{c}$ & $\mathrm{b}, \mathrm{c}$ \\
\hline & & & & & & Diani & $\mathrm{a}, \mathrm{c}$ & $\mathrm{b}, \mathrm{c}$ \\
\hline \multirow[t]{2}{*}{ Phosphate } & & & & & & Malindi & $\mathrm{a}, \mathrm{c}$ & $\mathrm{a}, \mathrm{c}$ \\
\hline & & & & & & Watamu & $\mathrm{b}, \mathrm{c}$ & $\mathrm{b}, \mathrm{c}$ \\
\hline Reefs & Fixed & 7 & & 2.10 & 0.0534 & Mombasa & $\mathrm{a}$ & $\mathrm{b}$ \\
\hline Seasons & Fixed & 1 & & 1.60 & 0.2103 & Kisite & $\mathrm{b}, \mathrm{c}$ & $\mathrm{b}, \mathrm{c}$ \\
\hline Reefs $\times$ Seasons & Fixed & 7 & & 1.29 & 0.2666 & Ras Iwatine & $\mathrm{a}, \mathrm{c}$ & $\mathrm{a}, \mathrm{c}$ \\
\hline Site (Reef) & Random & & 0 & & & Mpunguti & $\mathrm{b}$ & $\mathrm{b}$ \\
\hline \multirow[t]{2}{*}{ Residual } & Random & & 0.005 & & & Kanamai & $\mathrm{a}$ & a \\
\hline & & & & & & Diani & $\mathrm{b}$ & $\mathrm{b}$ \\
\hline
\end{tabular}


Table 2 (continued)

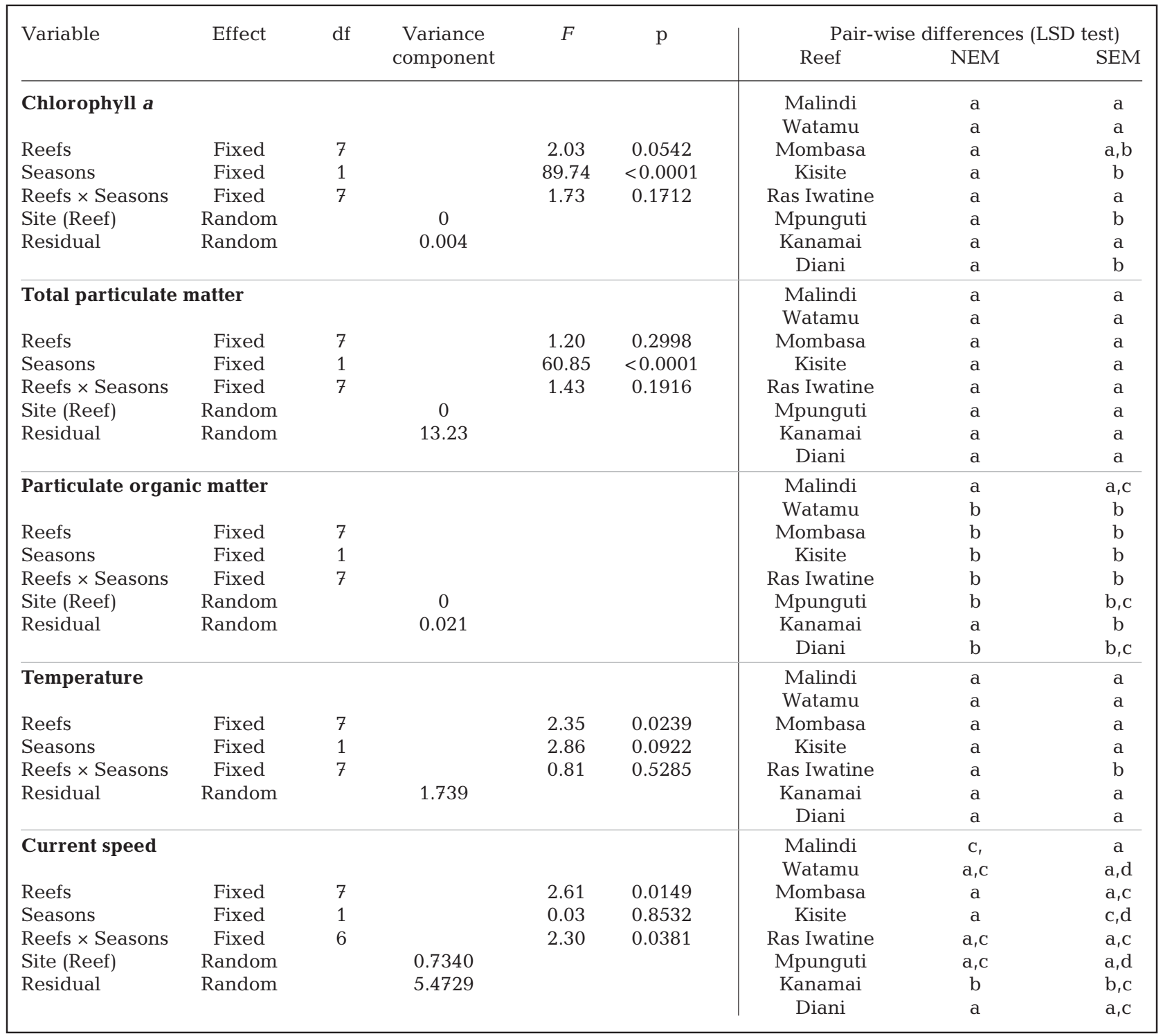

monsoon and maximum values during the southeast monsoon.

The cluster analysis performed to compare reefs by their physicochemical variables revealed 2 major clusters and several subclusters (Fig. 3a). Within the first major cluster, the Diani and Kisite MNPs had low concentrations of most chemical variables measured, in particular, low levels of phosphate, particulate organic matter, and chl a (Tables 1 \& 2). The exception was high nitrate + nitrite concentrations in Kisite MNP during the southeast monsoon. The Watamu and Mombasa MNPs and Mpunguti Reserve were distinguished within this first cluster by displaying intermediate concentrations of nutrients. Within this group, Mombasa MNP and Mpunguti were most sim- ilar, with similar values of most variables, except for higher concentrations of nitrate + nitrite during the southeast monsoon and phosphate during the northeast monsoon in Mombasa MNP. Watamu MNP was distinguished among these reefs by higher concentrations of chl a during the southeast monsoon. Malindi MNP differed from other reefs within this first cluster by having high levels for most chemical variables measured, in particular, high levels of ammonia and particulate organic matter during the northeast monsoon. Kanamai and Ras Iwatine formed the second cluster. These reefs were dissimilar from those forming the first cluster due to higher water temperature and lower current speed in addition to high levels of most chemical variables measured. 
a

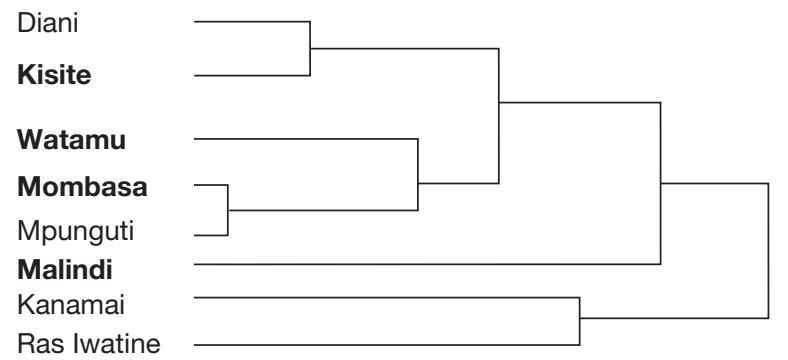

b
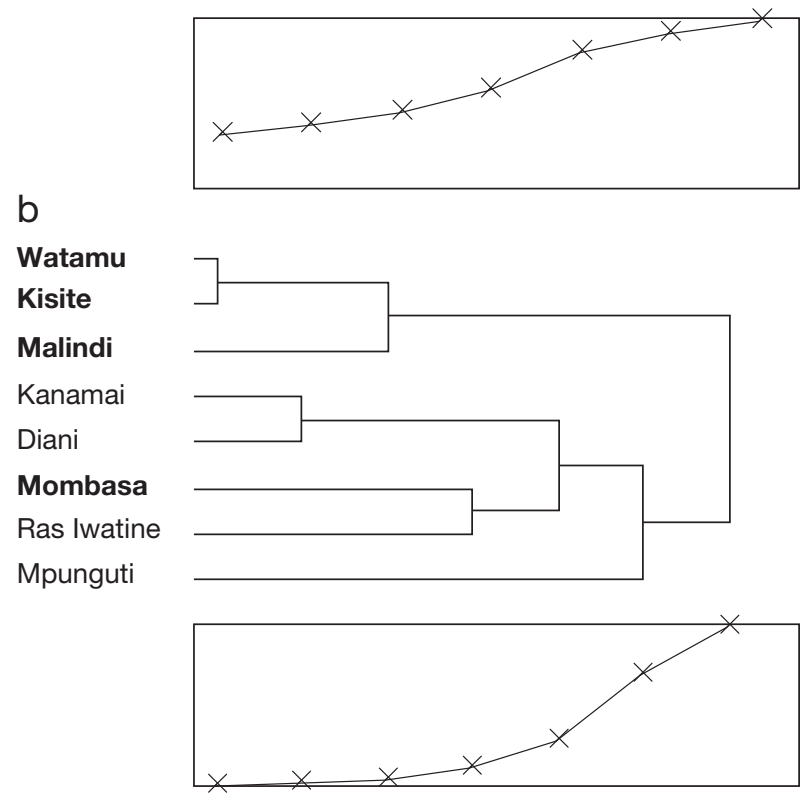

Fig. 3. Cluster analysis of the study sites for (a) physicochemical and (b) ecological variables, using the Ward method (Euclidean distance of standardized variables). Marine national parks in bold

\section{Ecological variables}

Cluster analysis comparing the studied reefs by their ecological variables revealed 2 major clusters (Fig. 3b). These clusters were, however, quite different from the clusters based on physicochemical variables. The first cluster was composed of 3 MNPs (Watamu, Kisite, and Malindi) characterized by high numbers of herbivorous fishes, high substrate complexity (rugosity), and low biomass of sea urchins (Table 3). Within this cluster, Malindi MNP was distinguished from other reefs by a higher cover of coralline algae, lower cover of turf algae, and higher parrotfish biomass.

Several small sub-clusters formed the second major cluster group. Within this group, Kanamai and Diani were most similar. Both reefs experience heavy fishing pressure and were characterized by low biomass of herbivorous fishes and high biomass of sea urchins

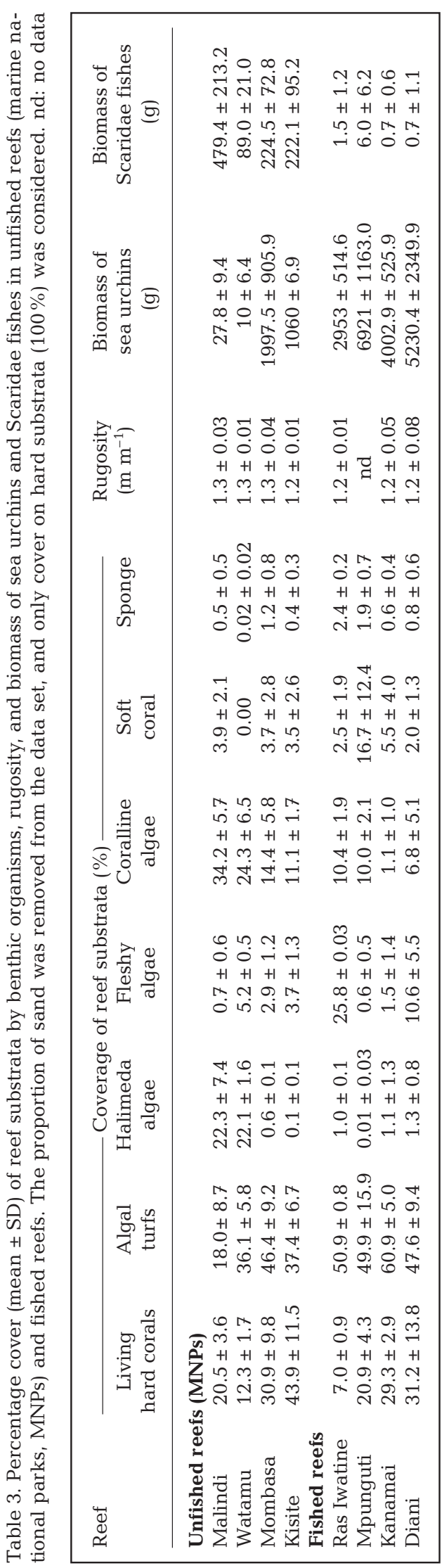


(Table 3). Mombasa is a marine park with high coral cover and high fish biomass, but it had intermediate biomass of sea urchins. Ras Iwatine Reserve had lower cover of live coral, higher cover of fleshy algae, and lower fish biomass but had a similar benthic cover of other taxa to Mombasa. Mpunguti Reserve was distinguished by having higher cover of soft coral and higher biomass of sea urchins than the other reefs.

\section{Macrobioerosion}

\section{Macroborer composition and macrobioerosion rates}

Macroborers were present in live corals (our control samples) at very low abundances, with only one coral disc observed with $0.5 \%$ of the total area bored by a clionaid sponge. In dead coral branches, 3 groups of boring macroorganisms accounted for most of the bioerosion: boring sponges (mostly Cliona spp. and Aka spp.), bivalves (Lithophaga spp.), and endolithic sipunculid and polychaete worms. Boring vermetids (gastropod mollusks) were also present in the bioeroding fauna but at very low abundances.

Four years after coral death, the macrobioerosion was mainly due to worms (sipunculids and polychaetes, $>60 \%$ area of occupancy of coral discs) on all reefs except for the Malindi and Watamu MNPs, where the contribution of bivalves and sponges to macrobioerosion was greater than that of worms (66 and $52 \%$ respectively; Fig. 4 a). The relative contribution of worms to macrobioerosion was significantly higher in Diani, Kanamai, and Mpunguti (65 to $70 \%$ area of occupancy of coral discs) than in the Malindi and Watamu MNPs (35 to $47 \%$ area of occupancy) and was intermediate on the other reefs (Table 4).

After 6 yr of exposure, worms were still the main agents of macrobioerosion at Diani, Kanamai, and Mpunguti (>54\% relative area of occupancy of coral discs; Fig. 4b). On all other reefs, the relative contribution of sponges to macrobioerosion increased with time of exposure, and sponges became the main agent of macrobioerosion $6 \mathrm{yr}$ after the death of the corals (Table 4, Fig. 4). The contribution of sponges to macrobioerosion was higher in the Malindi, Watamu, and Mombasa MNPs (66 to $75 \%$ ) than in Diani, Kanamai, and Mpunguti (33 to $44 \%$ ). The relative contribution of bivalves to macrobioerosion was generally low (0 to $10 \%$ ) and not significantly different between reefs or times of exposure (Table 4).

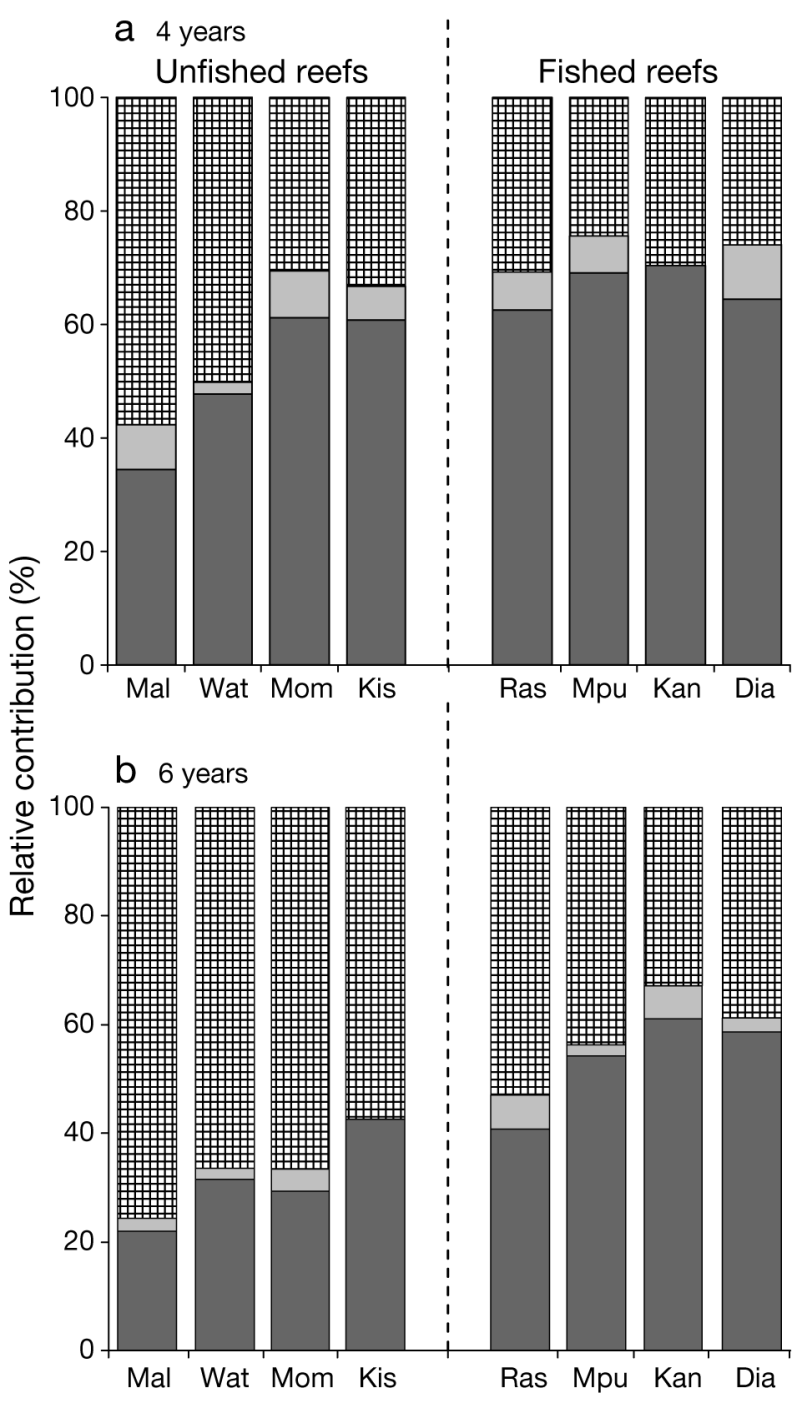

Fig. 4. Proportional contribution (\%) of the different groups of boring macroorganisms (worms, $\square$; bivalves, $\square$; sponges, 四) to macrobioerosion at 8 coral reefs along the Kenyan coast, (a) 4 yr and (b) 6 yr after the death of the corals. Mal: Malindi; Wat: Watamu; Mom: Mombasa; Kis: Kisite; Ras: Ras

Iwatine; Mpu: Mpunguti; Kan: Kanamai; Dia: Diani

Examination of the variance components for the relative contribution of different macroboring groups to total bioerosion indicated that 30 to $36 \%$ of the total variance in the random terms for worms and sponges was due to differences at sites within reefs and inter-colony differences (coral branches) and 25 to $26 \%$ was due to intra-colony differences (replicate discs) (Table 4). Most of the variance of random terms of the bivalves' relative contribution was centered at the inter-colony level (84\%) and less at the intracolony level (14\%).

Cumulative rates of macrobioerosion (measured after 4 and $6 \mathrm{yr}_{;} \mathrm{g} \mathrm{CaCO}_{3} \mathrm{~m}^{-2}$ ) were significantly differ- 
Table 4. Nested ANOVA mixed model of logit-transformed proportional contributions (\%) of different groups of boring organisms (worms, bivalves, and sponges) to macrobioerosion at 8 coral reefs along the Kenyan coast 4 and 6 yr after coral death. Least squares differences pair-wise test (LSD) on mean differences among reefs 4 and 6 yr after coral death. Means sharing the same letter are not statistically different. For random effects, the variance components are reported, while for fixed effects, the F-ratios and their probabilities are reported. df: ordinary least of squares degrees of freedom

\begin{tabular}{|c|c|c|c|c|c|c|c|c|}
\hline \multirow[t]{2}{*}{ Variable } & \multirow[t]{2}{*}{ Effect } & \multirow[t]{2}{*}{ df } & \multirow{2}{*}{$\begin{array}{c}\text { Variance } \\
\text { component }\end{array}$} & \multirow[t]{2}{*}{$F$} & \multirow[t]{2}{*}{$\mathrm{p}$} & \multicolumn{3}{|c|}{ Pair-wise differences (LSD test) } \\
\hline & & & & & & Reefs & $4 \mathrm{yr}$ & 6 yr \\
\hline Worms & & & & & & Malindi & a & $\mathrm{a}$ \\
\hline Reefs & Fixed & 7 & & 8.4 & $<0.0001$ & Watamu & $\mathrm{a}, \mathrm{c}$ & $\mathrm{a}, \mathrm{c}$ \\
\hline Time & Fixed & 1 & & 29.1 & $<0.0001$ & Mombasa & $\mathrm{b}, \mathrm{c}$ & $\mathrm{a}, \mathrm{c}$ \\
\hline Reef $\times$ Time & Fixed & 7 & & 0.82 & 0.5707 & Kisite & $\mathrm{b}, \mathrm{c}$ & $\mathrm{C}$ \\
\hline & & & & & & Ras Iwatine & $\mathrm{b}, \mathrm{c}$ & $\mathrm{C}$ \\
\hline Sites (Reefs) & Random & & 0.4188 & & & Mpunguti & $\mathrm{b}$ & $\mathrm{b}$ \\
\hline Coral branches (Reef sites) & Random & & 0.3663 & & & Kanamai & $\mathrm{b}$ & $\mathrm{b}$ \\
\hline Coral discs (Coral branches) & Random & & 0.4211 & & & Diani & $\mathrm{b}$ & $\mathrm{b}$ \\
\hline Bivalves & & & & & & Malindi & a & a \\
\hline Reefs & Fixed & 7 & & 0.58 & 0.7685 & Watamu & a & a \\
\hline Time & Fixed & 1 & & 0.00 & 0.9938 & Mombasa & a & $\mathrm{a}$ \\
\hline Reef $\times$ Time & Fixed & 7 & & 0.37 & 0.9175 & Kisite & a & $\mathrm{a}$ \\
\hline Sites (Reefs) & Random & & & & & Ras Iwatine & $\mathrm{a}$ & a \\
\hline Coral branches (Reef sites) & Random & & 0.01811 & & & Mpunguti & $\mathrm{a}$ & a \\
\hline & Random & & 1.3099 & & & Kanamai & $\mathrm{a}$ & a \\
\hline Coral discs (Coral branches) & Random & & 0.2232 & & & Diani & $\mathrm{a}$ & $\mathrm{a}$ \\
\hline Sponges & & & & & & Malindi & $\mathrm{a}$ & $\mathrm{a}$ \\
\hline Reefs & Fixed & 7 & & 8.10 & $<0.0001$ & Watamu & $\mathrm{a}$ & $\mathrm{a}, \mathrm{d}$ \\
\hline Time & Fixed & 1 & & 35.44 & $<0.0001$ & Mombasa & $\mathrm{b}$ & $\mathrm{a}$ \\
\hline Reef $\times$ Time & Fixed & 7 & & 1.02 & 0.4147 & Kisite & $\mathrm{b}$ & $\mathrm{b}, \mathrm{d}$ \\
\hline & & & & & & Ras Iwatine & $\mathrm{b}$ & $\mathrm{b}, \mathrm{d}$ \\
\hline Sites (Reefs) & Random & & 0.5285 & & & Mpunguti & $\mathrm{b}$ & $\mathrm{b}, \mathrm{c}$ \\
\hline Coral branches (Reef sites) & Random & & 0.5378 & & & Kanamai & $\mathrm{b}$ & $\mathrm{C}$ \\
\hline Coral discs (Coral branches) & Random & & 0.4097 & & & Diani & $\mathrm{b}$ & $\mathrm{C}$ \\
\hline
\end{tabular}

ent between reefs and times of exposure, whereas yearly macrobioerosion rates $\left(\mathrm{g} \mathrm{CaCO}_{3} \mathrm{~m}^{-2} \mathrm{yr}^{-1}\right.$ ) were significantly different among reefs but did not change significantly over time (Table 5). The LSD means comparisons showed 2 groups of reefs for cumulative macrobioerosion and yearly macrobioerosion rate measurements (Fig. 5). One group of reefs comprised the Malindi, Watamu, and Mombasa MNPs, Ras Iwatine Reserve and Kanamai reef, where macrobioerosion was highest (mean \pm SE: $785 \pm 96$ to $1135 \pm 118 \mathrm{~g} \mathrm{CaCO}_{3} \mathrm{~m}^{-2} 4 \mathrm{yr}$ after coral death and $1402 \pm 163$ to $2149 \pm 439 \mathrm{~g} \mathrm{CaCO}_{3} \mathrm{~m}^{-2} 6 \mathrm{yr}$ after coral death; Appendix 1). The other group included Kisite MNP, Mpunguti Reserve, and Diani reef, where macrobioerosion rates were lowest $(534 \pm 91$ to $719 \pm 74 \mathrm{~g}$ $\mathrm{CaCO}_{3} \mathrm{~m}^{-2} 4 \mathrm{yr}$ after coral death and $837 \pm 111$ to $1064 \pm 66 \mathrm{~g} \mathrm{CaCO}_{3} \mathrm{~m}^{-2} 6$ yr after coral death). Cumulative bioerosion significantly increased over time in the Watamu and Mombasa MNPs, Mupuguti Reserve, and Kanamai reef (LSD p $<0.05$; Table 5).

Cumulative boring rates by worms and sponges were not constant through time on different reefs, as indicated by the significant Reef $\times$ Time interactions
(Table 5). After $4 \mathrm{yr}$ of exposure, boring rates by worms were $~ 1.4$ - to 3-fold higher at Diani, Kanamai, and Ras Iwatine than on all other reefs (Fig. 6a, Appendix 1). After 6 yr since the coral death, boring rates by worms were 1.5- to 2-fold higher in Kanamai, Ras Iwatine, and Mombasa MNP than in Diani, Mpunguti, and Kisite and 2.5- to 3-fold higher than in the Malindi and Watamu MNPs (Fig. 6b). Boring by worms increased significantly over time in the Kisite and Mombasa MNPs and the Mpunguti and Ras Iwatine Reserves. Sponge boring rates, after 4 yr of exposure, were $\sim 2$ - to 4 -fold higher in Ras Iwatine Reserve and the Malindi and Mombasa MNPs when compared with Mpunguti Reserve and Kanamai and Diani reefs. After 6 yr, maximum sponge boring rates were recorded in the Malindi and Watamu MNPs, with rates 1.3- to 6-fold higher than at the other reefs. Although boring by sponges tended to increase over time on most reefs, this increase was statistically significant only for Diani and Watamu MNP.

Rates of bioerosion by bivalves were low on all reefs (Fig. 6a,b) and exhibited no significant differences between reefs or times of exposure (Table 5). 
Table 5. Nested ANOVA mixed model of $\log (\mathrm{x}+0.01)$ transformed rates of yearly rates of macroboring $\left(\mathrm{g} \mathrm{CaCO}_{3} \mathrm{~m}^{-2} \mathrm{yr}^{-1}\right)$, cumulative rates of boring by all macroborers combined and cumulative boring rates $\left(\mathrm{g} \mathrm{CaCO}_{3} \mathrm{~m}^{-2}\right)$ by individual groups of boring macroorganisms (worms, mollusks, and sponges) at 8 coral reefs along the Kenyan coast 4 and 6 yr after coral death. Least squares differences pair-wise test (LSD) on means differences among reefs 4 and 6 yr after coral death. Means sharing the same letter are not statistically different. For random effects, the variance components are reported, while for fixed effects, the F-ratios and their probabilities are reported. df: ordinary least of squares degrees of freedom

\begin{tabular}{|c|c|c|c|c|c|c|c|c|}
\hline \multirow[t]{2}{*}{ Variable } & \multirow[t]{2}{*}{ Effect } & \multirow[t]{2}{*}{ df } & \multirow{2}{*}{$\begin{array}{c}\text { Variance } \\
\text { component }\end{array}$} & \multirow[t]{2}{*}{$F$} & \multirow[t]{2}{*}{$\mathrm{p}$} & \multicolumn{3}{|c|}{ Pair-wise differences (LSD test) } \\
\hline & & & & & & Reefs & $4 \mathrm{yr}$ & 6 yr \\
\hline Yearly bioerosion rates & & & & & & Malindi & $\mathrm{b}$ & $\mathrm{b}$ \\
\hline Reefs & Fixed & 7 & & 7.29 & $<0.0001$ & Watamu & $\mathrm{b}$ & $\mathrm{b}$ \\
\hline Time & Fixed & 1 & & 0.16 & 0.6899 & Mombasa & $\mathrm{b}$ & $\mathrm{b}$ \\
\hline Reef $\times$ Time & Fixed & 7 & & 1.56 & 0.1446 & Kisite & $\mathrm{a}$ & $\mathrm{a}$ \\
\hline Sites (Reefc) & Random & & 001150 & & & Ras Iwatine & $\mathrm{b}$ & $\mathrm{b}$ \\
\hline & Random & & 0.01150 & & & Mpunguti & $\mathrm{a}$ & $\mathrm{a}$ \\
\hline Coral branches (Reef sites) & Random & & 0.006430 & & & Kanamai & $\mathrm{b}$ & $\mathrm{b}$ \\
\hline & & & & & & Diani & a & $\mathrm{a}$ \\
\hline Cumulative bioerosion & & & & & & Malindi & $\mathrm{b}$ & $\mathrm{b}$ \\
\hline Reefs & Fixed & 7 & & 7.29 & $<0.0001$ & Watamu & $\mathrm{b}$ & $\mathrm{b}$ \\
\hline Time & Fixed & 1 & & 37.08 & $<0.0001$ & Mombasa & $\mathrm{b}$ & $\mathrm{b}$ \\
\hline Reef $\times$ Time & Fixed & 7 & & 1.56 & 0.1446 & Kisite & a & $\mathrm{a}$ \\
\hline Sites (Reefs) & Random & & 0.01150 & & & Ras Iwatine & $\mathrm{b}$ & $\mathrm{b}$ \\
\hline Coral branches (Reef sites) & Random & & 0.006430 & & & Mpunguti & a & a \\
\hline Coral discs (Coral branches) & Random & & 0.1210 & & & Kanamai & $\mathrm{b}$ & $\mathrm{b}$ \\
\hline & & & & & & Diani & a & a \\
\hline Worm boring rates & & & & & & Malindi & $\mathrm{C}$ & $\mathrm{C}$ \\
\hline Reefs & Fixed & 7 & & 12.7 & $<0.0001$ & Watamu & $\mathrm{b}$ & C \\
\hline Time & Fixed & 1 & & 28.4 & $<0.0001$ & Mombasa & $\mathrm{C}$ & $\mathrm{b}$ \\
\hline Reef $\times$ Time & Fixed & 7 & & 10.31 & $<0.0001$ & Kisite & $\mathrm{b}, \mathrm{c}$ & $\mathrm{a}$ \\
\hline Sites (Reefs) & Random & & 0.0038 & & & Ras Iwatine & $\mathrm{a}$ & $\mathrm{b}$ \\
\hline Coral branches (Reef sites) & Random & & 0.0030 & & & Mpunguti & $\mathrm{b}, \mathrm{c}$ & a \\
\hline & Random & & 0.0283 & & & Kanamai & $\mathrm{a}$ & $\mathrm{b}$ \\
\hline Coral discs (Coral branches) & Random & & 0.1695 & & & Diani & a & $\mathrm{a}$ \\
\hline Bivalve boring rates & & & & & & Malindi & a & a \\
\hline Reefs & Fixed & 7 & & 1.98 & 0.2138 & Watamu & a & a \\
\hline Time & Fixed & 1 & & 0.05 & 0.8321 & Mombasa & a & $\mathrm{a}$ \\
\hline Reef $\times$ Time & Fixed & 7 & & 1.58 & 0.1391 & Kisite & a & $\mathrm{a}$ \\
\hline Sites (Reefs) & Random & & 0.0015 & & & Ras Iwatine & $\mathrm{a}$ & $\mathrm{a}$ \\
\hline Coral branches (Reef sites) & Random & & 0.0061 & & & Mpunguti & a & a \\
\hline$C$ ral diccs $C$ ral hranches & Raniniti & & 0.0061 & & & Kanamai & a & a \\
\hline Coral discs (Coral branches) & Random & & 0.6832 & & & Diani & a & a \\
\hline Sponge boring rates & & & & & & Malindi & $\mathrm{b}$ & C \\
\hline Reefs & Fixed & 7 & & 9.55 & $<0.0001$ & Watamu & $\mathrm{c}, \mathrm{d}$ & $\mathrm{C}$ \\
\hline Time & Fixed & 1 & & 0.56 & 0.4643 & Mombasa & $\mathrm{b}$ & a \\
\hline Reef $\times$ Time & Fixed & 7 & & 4.60 & $<0.0001$ & $\begin{array}{c}\text { Kisite } \\
\text { Ras Iwatine }\end{array}$ & $\mathrm{d}$ & $a, b$ \\
\hline Sites (Reefs) & Random & & 0.3030 & & & $\begin{array}{l}\text { Ras Iwatıne } \\
\text { Mpunguti }\end{array}$ & $\begin{array}{c}\mathrm{b}, \mathrm{c} \\
\mathrm{a}\end{array}$ & $\begin{array}{c}\mathrm{a}, \mathrm{b} \\
\mathrm{b}\end{array}$ \\
\hline Coral branches (Reef sites) & Random & & 0.1711 & & & Kanamai & $\mathrm{a}, \mathrm{d}$ & $\mathrm{a}$ \\
\hline Coral discs (Coral branches) & Random & & 1.2091 & & & Diani & $\mathrm{a}$ & $\mathrm{a}$ \\
\hline
\end{tabular}

An estimation of the variance components for total macrobioerosion rates and bioerosion rates by the different groups of borers indicated that 72 to $99 \%$ of the total variance of the random terms was due to differences at the intra-colony level, 0.9 to $14 \%$ was due to differences at the inter-colony level, and 0.2 to $18 \%$ was due to differences between sites within reefs (Table 5).

\section{Relationships between macroborers, water quality, and ecological variables}

Total macrobioerosion rates increased linearly with increasing concentrations of chl a on the 8 reefs studied, with a 1.6- to 2-fold increase in macrobioerosion along the observed chl a gradient from 0.26 to $0.45 \mu \mathrm{g} \mathrm{l}^{-1}, 4$ and $6 \mathrm{yr}$ after coral death $(\mathrm{r}=0.74, \mathrm{p}=$ 

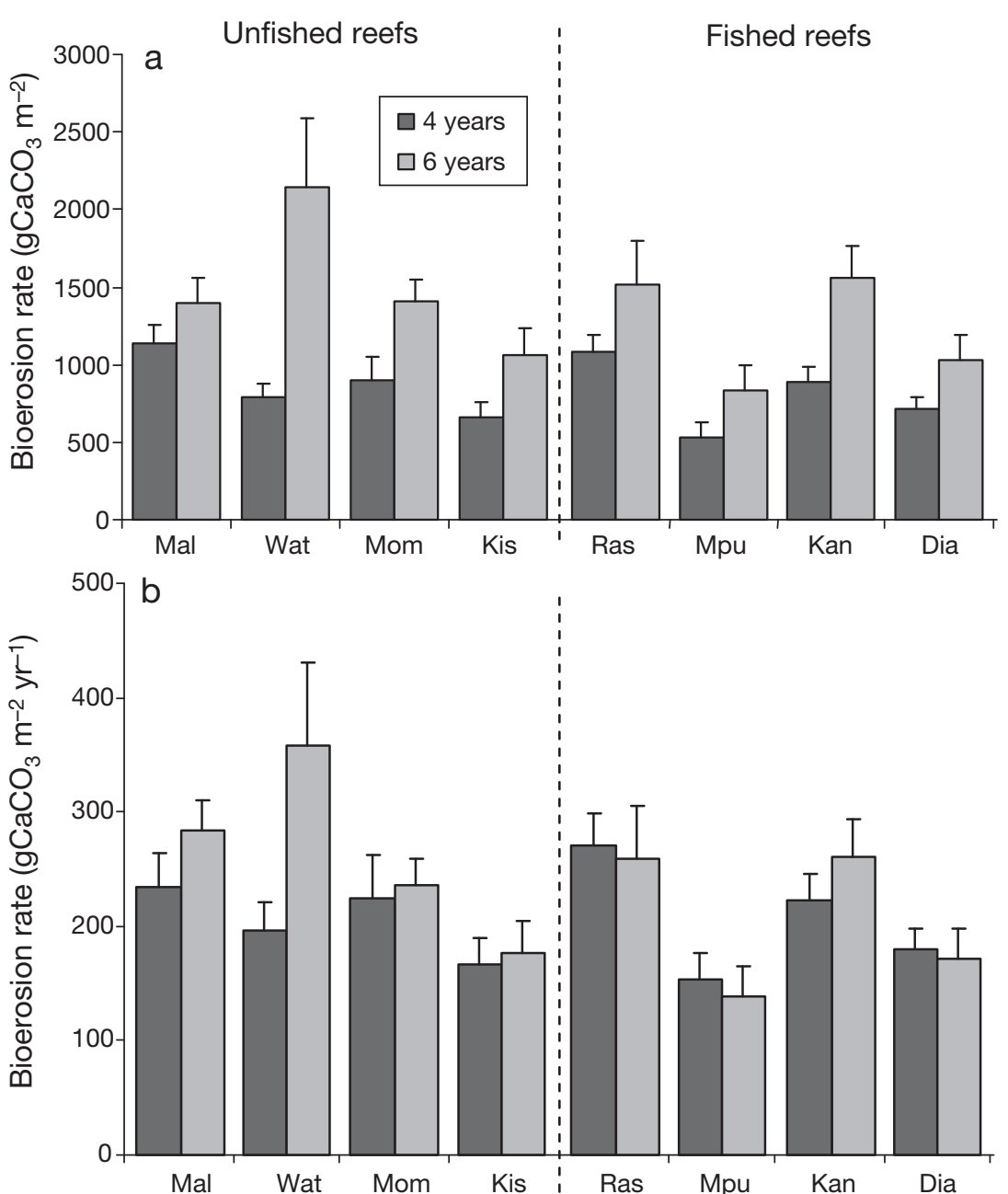

Fig. 5. (a) Total cumulative macrobioerosion rates (mean $+\mathrm{SE}, \mathrm{g} \mathrm{CaCO}_{3} \mathrm{~m}^{-2}$ ) and (b) yearly total macrobioerosion rates (mean $+\mathrm{SE}, \mathrm{g} \mathrm{CaCO}_{3} \mathrm{~m}^{-2} \mathrm{yr}^{-1}$ ) at 8 coral reefs along the Kenyan coast, 4 and $6 \mathrm{yr}$ after the death of the corals. Abbreviations as in Fig. 4

0.03 after 4 yr of coral death and $\mathrm{r}=0.83, \mathrm{p}=0.01$ after 6 yr of coral death, Fig. 7a). Sponge bioerosion rates also increased linearly with chl $a$, with a 5 -fold increase along the chl a gradient 6 yr after coral death $(r=0.73, p=0.04$; Fig. 7b). Total macrobioerosion and sponge boring rates were, however, not correlated to the TPM or POM concentration $(\mathrm{r}<0.53$, $\mathrm{p}>0.05$ ). Worm and bivalve boring rates were not significantly correlated to any of the measured environmental variables $(r<0.68, p>0.05)$.

The relative contribution of different macroboring groups to macrobioerosion showed a strong relationship with the ecological condition of the reefs (Table 6). The contribution of worms to macrobioerosion was lower on reefs with denser calcareous and encrusting coralline alga cover, lower 3-dimensional complexity (rugosity) of reefs, and higher biomass of scarid fishes and was higher in reefs with denser algal turf cover and higher sea urchin biomass.

The relative contribution of sponges to macrobioerosion followed an inverse trend to that observed for worms. Sponge contribution was higher in reefs with denser calcareous and encrusting coralline alga cover, larger 3dimensional complexity (rugosity), and higher biomass of scarid fishes but was lower on reefs with denser algal turf cover and higher sea-urchin biomass. The proportional contribution of bivalves to macrobioerosion could not be correlated with any of the measured ecological variables.

The relative influences of ecological and water quality variables on macroborer groups and bioerosion rates are best depicted in the canonical correspondence analysis (Fig. 8). The first 2 canonical axes accounted for $54 \%$ and $30 \%$ of the total variability, respectively. The analysis clearly separated macroborer groups and bioerosion rates according to reef management (fished and unfished reefs), with worms dominating bioeroding communities in fished reefs and sponges dominating communities in unfished reefs. The relative abundance of worms was primarily related to sea urchin biomass, whereas sponge relative abundance was related to the biomass of parrotfishes. Total bioerosion rates and bioerosion rates by sponges were primarily influenced by chl a concentrations in reef waters, in particular, the rates measured $6 \mathrm{yr}$ after coral death. Sponge bioerosion rates $4 \mathrm{yr}$ after coral death were moderately influenced by TPM concentrations. POM did not greatly influence bioerosion rates or macroborer community composition.

\section{DISCUSSION}

The present study took advantage of an event of coral mass mortality that made it possible to pinpoint the exact month that the colonies of branching Porites died (McClanahan et al. 2001). Branching Porites is a ubiquitous coral group in Kenya, common at all of our study sites and present across various environmental conditions, which allowed the evaluation of spatial 


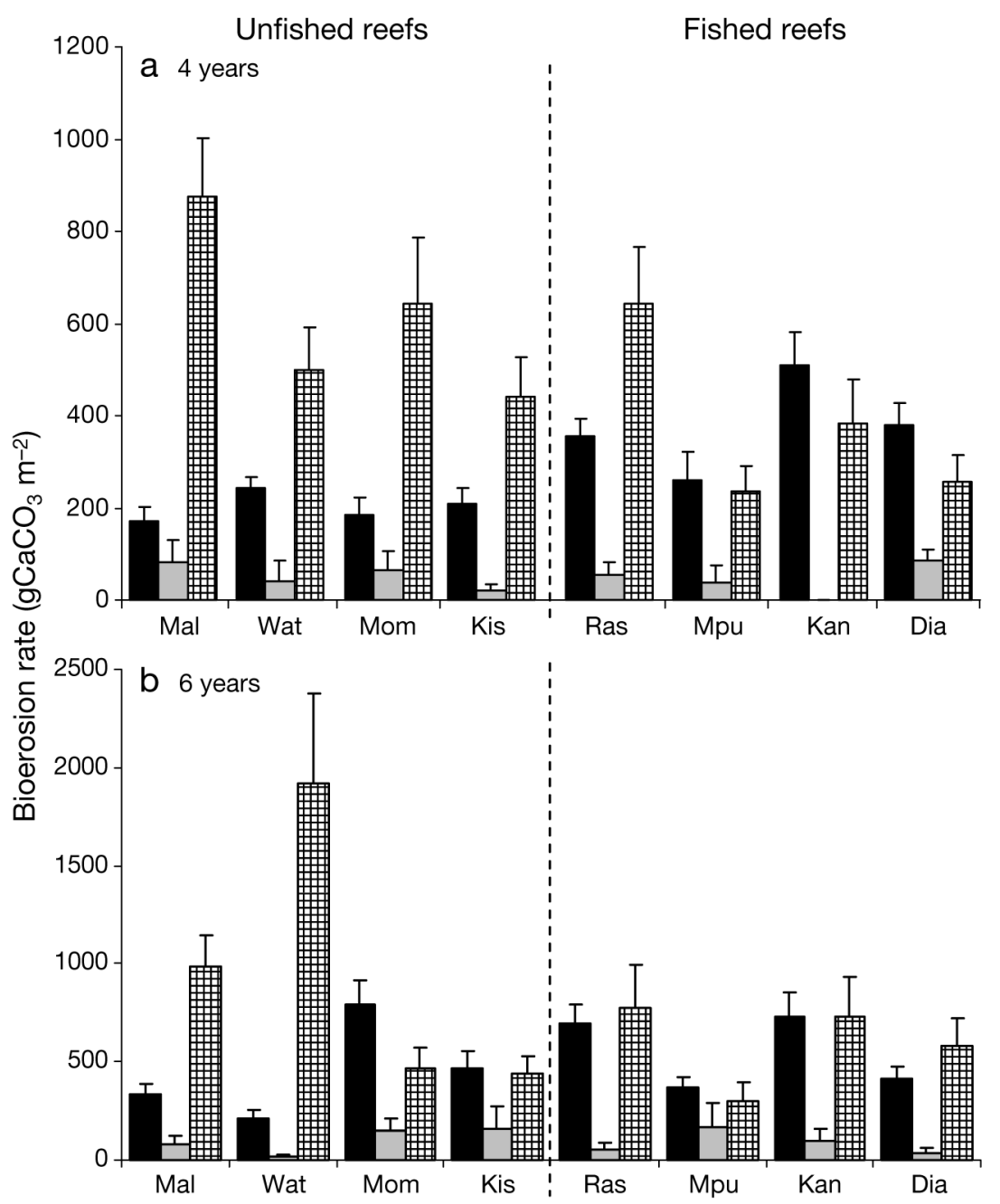

Fig. 6. Cumulative bioerosion rates (mean $+\mathrm{SE}, \mathrm{g} \mathrm{CaCO}_{3} \mathrm{~m}^{-2}$ ) by worms (ם), bivalves ( $\square$ ) and sponges (四) at 8 coral reefs along the Kenyan coast, (a) 4 yr and (b) 6 yr after the death of the corals. Abbreviations as in Fig. 4

and temporal patterns of macrobioerosion after the 1998 mass coral mortality. Consequently, it was possible to avoid the common practice of sacrificing live coral colonies to make blocks for colonization and examining these blocks over time (Kiene \& Hutchings 1992, PeyrotClausade et al. 1995). Typically, coral blocks have to be exposed for $>3$ yr to reveal differences in macroborer communities and macrobioerosion rates (Kiene \& Hutchings 1992, 1994, Pari et al. 1998, Chazottes et al. 2002, Tribollet \& Golubic 2005). The 4 and 6 yr time intervals used here did not include the first 3 yr that were commonly targeted in other studies and show that changes in the community are evident at some reefs even 6 yr after coral mortality.

\section{Macroborer community composition and bioerosion rates}

Macrobioerosion in the live branching Porites colonies examined was extremely low ( $<1 \mathrm{mg} \mathrm{CaCO}_{3} \mathrm{~m}^{-2}$ ). These control corals were col-

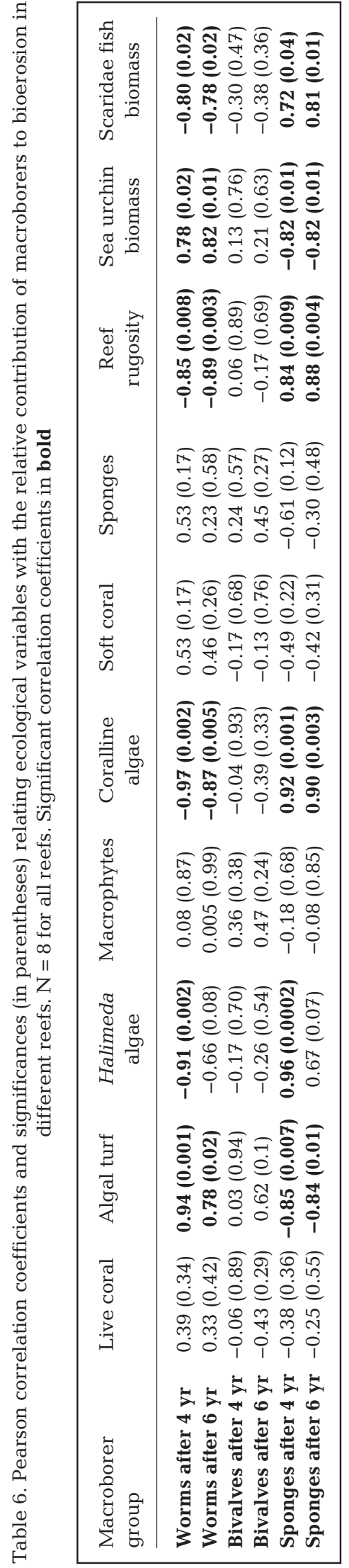




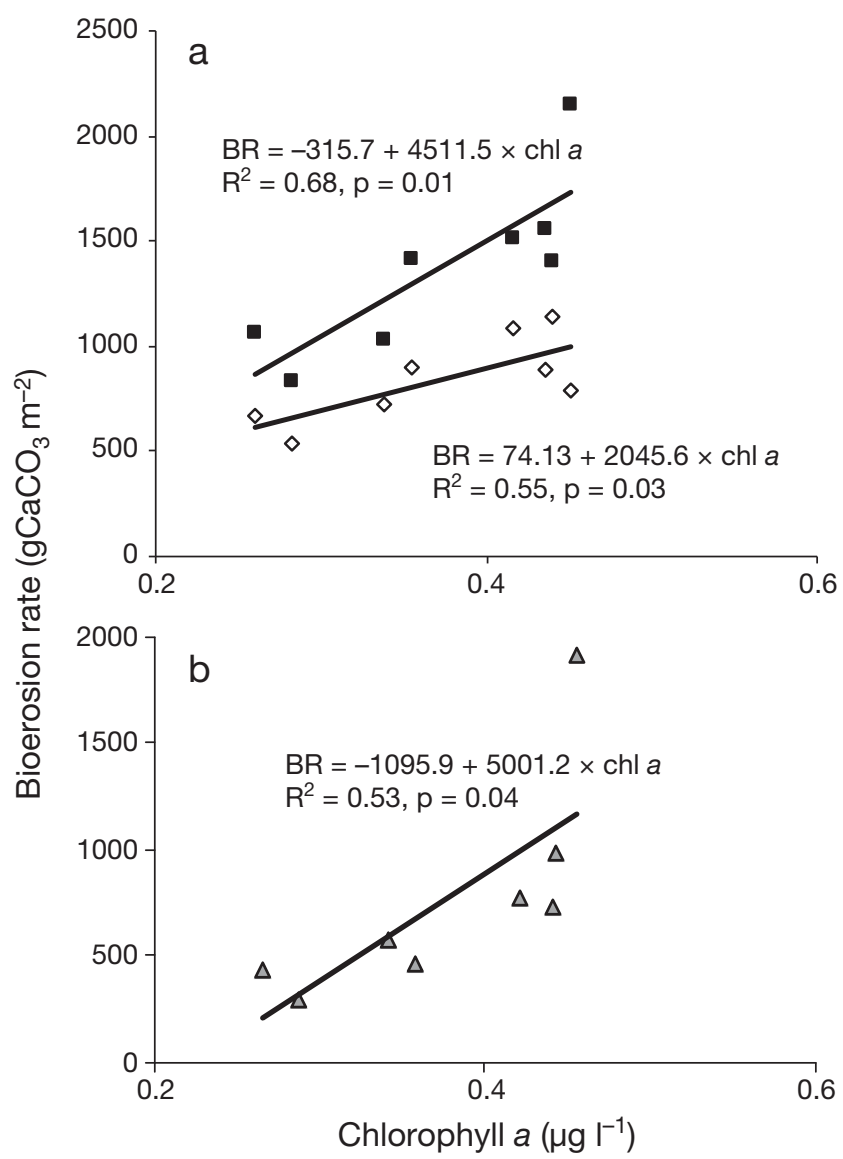

Fig. 7. Linear regressions of (a) total cumulative macrobioerosion rates $\left(\mathrm{BR}, \mathrm{gCaCO}_{3} \mathrm{~m}^{-2}\right), 4(\diamond)$ and $6 \mathrm{yr}(\boldsymbol{\square})$ after coral death, and (b) bioerosion rates by sponges $4 \mathrm{yr}$ after coral death versus chlorophyll a concentrations at 8 coral reefs along the Kenyan coast

lected in Kanamai, a reef experiencing high levels of inorganic nutrients and particulate organic matter, which suggests that macrobioerosion is mainly established after death for branching Porites in Kenya. These findings contrast with studies on the GBR and in Indonesia, where boring lithophagid bivalves and sponges were present in living massive corals in densities increasing with eutrophication (Sammarco \& Risk 1990, Holmes et al. 2000). The low abundance of lithophagid bivalves found in corals in Kenya may in part explain these contrasting findings. An alternative explanation is a low susceptibility of branching Porites corals to sponge and bivalve larvae settlement. A study of the colonization abilities of Cliona orentalis in the central GBR detected effective defense reactions of the branching corals $P$. cylindrica and $P$. rus against grafted sponge tissue (Schönberg \& Wilkinson 2001). The potential for a defense reaction by branching Porites against macroboring organism larvae requires further investigation.
Bioerosion and the composition of macroborers changed over space and time in dead coral skeletons. Six years after the death of these corals, worms (polychaetes and sipunculids) were the main agent of bioerosion on reefs with lower abundance of calcareous and encrusting coralline algae, less structural complexity, and higher biomass of sea urchins. These were the heavily fished reefs, where experiments with grazers have shown that sea urchins reduce the cover of coralline algae (O'Leary \& McClanahan 2010). Mature macrobioeroding communities dominated by sponges, in contrast, prevailed in unfished marine parks, and these findings indicate that fisheries management and the abundance of fishes and sea urchins can play an important role in the community structure of macroborers.

The influence of grazing pressure on macroborer species composition and succession has been well studied in the GBR and found to keep macroborer communities in an early successional state (Sammarco et al. 1987, Kiene \& Hutchings 1994, Risk et al. 1995, Tribollet \& Golubic 2005). Newly exposed substratum is colonized by pioneer borers, such as polychaetes and sipunculids, while larger and slower colonizing macroborers, such as bivalves and sponges, are initially uncommon. Fishes were the main grazers in the GBR studies, whereas sea urchins were the dominant grazers on fished Kenyan reefs and affected macroborer species composition more strongly than fishes. The more localized and intense grazing of sea urchins (Bak 1990, Chazottes et al. 1995, Reaka-Kudla et al. 1996, Carreiro-Silva \& McClanahan 2001) can reduce coralline algal cover (O'Leary \& McClanahan 2010) and is associated with reduced reef topographic complexity (McClanahan \& Shafir 1990). Early macroborer settlers are extremely vulnerable to grazers that feed on epilithic and endolithic algae (Hutchings et al. 1992, 2005). Progressively, as these macroborers grow and penetrate deeper into the substrate, they become less susceptible to grazing.

A full ecological succession of macroborers from worm- to sponge-dominated communities was only observed in the Mombasa and Kisite MNPs and Ras Iwatine Reserve, where sea-urchin biomass was low and water quality was moderate. In the Malindi and Watamu MNPs, sponges dominated macroborer communities after 4 yr of exposure. On these 2 reefs, high concentrations of chl a and POM may have accelerated the succession of the macroborer community, leading to sponge dominance earlier than on the other reefs. Several studies have shown increases in the abundance of filter- and detritus-feeding 


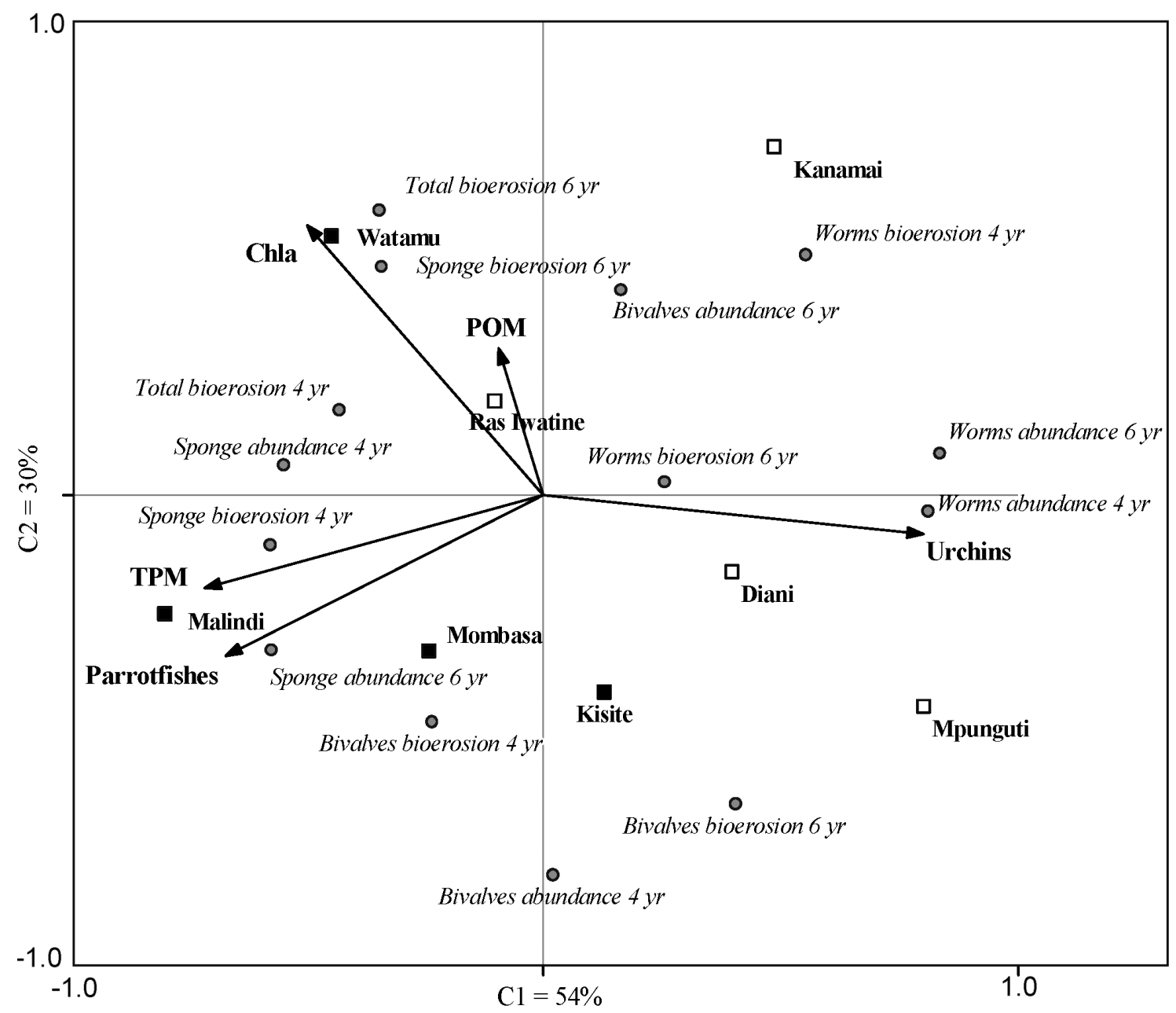

Fig. 8. Canonical correspondence analysis biplot of studied reefs within marine national parks ( $\square$ unfished reefs) or unprotected reefs ( $\square$ fished reefs), macroborer relative abundance, and bioerosion rates in relation to 5 predictor variables: sea urchins and parrotfish biomass, total particulate matter (TPM), particulate organic matter (POM), and chlorophyll a (chl a) concentrations. Percentages of constrained variance accounted for by the 2 first canonical axes are given in each axis

macroborers in organically polluted waters (Risk \& McGeachy 1978, Tribollet et al. 2002, Tribollet \& Golubic 2005). Among the different macroborer taxa, clionaid sponges respond most strongly to the nutrient and organic matter content of reef waters (Rose \& Risk 1985, Holmes 2000, Ward-Paige et al. 2005).

In the present study, total macrobioerosion rates were positively correlated with the concentrations of $\mathrm{chl} a$ in reef waters and thus with the planktonic productivity in different reefs. The highest rates were recorded in the Watamu and Malindi MNPs, where sponges accounted for $80 \%$ of the total macroboring. Boring rates by sponges did not, however, show any significant correlation with POM, even though bioerosion rates were highest on the reefs with high levels of POM (e.g. Malindi, Watamu, and Kanamai). Increased plankton productivity and POM directly benefit bioeroders by increasing their food supply (Birkeland 1988). Nevertheless, boring rates by bivalves and worms were not significantly related with any water quality variables, suggesting that sponges were more sensitive to changes in water quality.

The strong relation between total macrobioerosion and the trophic condition of a given reef agrees with previous studies examining bioerosion in living massive Porites and coral rubble in Indonesia and the GBR (Edinger et al. 2000, Holmes et al. 2000, Le Grand \& Fabricius 2011). Macrobioerosion rates recorded on our most eutrophic reefs after 4 yr were comparable to rates found in coral blocks exposed for 3 to $4 \mathrm{yr}$ in inshore areas of the GBR (Tribollet \& Golubic 2005, Osorno et al. 2005).

Algal cover has also been suggested to influence macrobierosion. Increased cover of macroalgae and 
crustose corallines in high nutrient areas were suggested to protect the underlying substrates and reduce macrobioerosion rates at Reunion Island (Indian Ocean) (Chazottes et al. 2002). In Kenya, however, the highest macrobioerosion and sponge boring rates were recorded on reefs with high coralline and macroalgae cover. Discrepancies between these studies could be related to the time of exposure of the substrate ( $1 \mathrm{yr}$ in Reunion Island vs. 4 to $6 \mathrm{yr}$ in Kenya) and composition of the boring community. At Reunion Island, only boring worms were present in the experimental blocks, whereas in our study, the boring communities were dominated by sponges.

Annual rates of erosion were not constant over time in the present study, similar to previous results using experimental blocks on the GBR (Kiene \& Hutchings 1994, Tribollet \& Golubic 2005) and natural substrates in Belize (Lescinsky et al. 2008). It is likely that space becomes limiting and macrobioerosion proceeds at a lower rate as substratum is increasingly bored. Similar patterns have been observed for microbioerosion processes on dead coral, suggesting that bioerosion rates do not increase linearly but probably level off over time (Tribollet \& Golubic 2005, Tribollet 2008).

Branching corals may be more susceptible to weakening and breakage than massive corals and coral blocks, which could potentially lead to underestimations of bioerosion rates. However, the estimates reported here were comparable to values reported for coral blocks (e.g. Tribollet \& Golubic 2005, Osorno et al. 2005). The use of natural substrates to quantify bioerosion rates requires frequent visits to the sites to eliminate the possibility of sampling corals that died at different times, which would affect findings for macrobioerosion rates. Despite these limitations, the present work and a previous study in Belize (Lescinsky 2004, Lescinsky et al. 2008) indicate that natural disturbance experiments are a useful alternative to the experimental blocks frequently used to estimate rates of bioerosion. The approach used here may become increasingly important to evaluate the effects of coral bleaching and mortality on the processes of reef growth.

\section{Macroborers as indicators of eutrophication}

The management of coral reef ecosystems requires suitable biological indicators of water quality (Cooper et al. 2009). The specificity of the biological response to the stressor of interest and the variability or consistency of the response at a range of spatial and temporal scales are important criteria to judge the suitability of bioindicators (Cooper et al. 2009). Consistent responses of macroborers to eutrophication in many regions improve their value as bioindicators for comparisons across regions, such as the GBR (Sammarco \& Risk 1990, Risk et al. 1995, Tribollet et al. 2002, Tribollet \& Golubic 2005, Le Grand and Fabricius 2011), Caribbean (Rose \& Risk 1985, Holmes 2000, Ward-Paige et al. 2005), Eastern Pacific (Fonseca et al. 2006), Indonesia (Edinger et al. 2000, Holmes et al. 2000), and the Western Indian Ocean (the present study). The present study demonstrates that macrobioerosion rates responded strongly to water quality, but the community of macroborers can change with the type of grazers on the reef. Sponges were more sensitive to changes in water quality than worms or bivalves, but sponge boring rates were significantly related to water quality changes only 6 yr after coral death. Consequently, the dominant bioeroder groups can reflect the interaction between water quality and fisheries status, and therefore, total macrobioerosion maybe a more appropriate indicator than selecting a particular group of bioeroders.

One limitation is that macroborers are often slow to respond to changes in water quality, and differences between reefs may take several years to be detected (Kiene \& Hutchings 1992, 1994, Pari et al. 1998, Chazottes et al. 2002, Tribollet \& Golubic 2005), as exemplified by the observed changes over the 4 and $6 \mathrm{yr}$ intervals in this study. Therefore, macroborers may be more appropriate for long- than short-term monitoring (Cooper et al. 2008, 2009).

Ecological research has demonstrated the effectiveness of Kenyan MPAs for increasing the abundance and diversity of finfish and controlling seaurchin populations, with resulting benefits for calcification and reef framework complexity (McClanahan \& Arthur 2001, O'Leary \& McClanahan 2010). The present study shows that some of the oldest marine parks have the highest bioerosion rates, which are influenced by eutrophication and human influences outside the direct control of marine and fishery management. Intensive erosion of carbonates has the potential to undermine reef growth and diminish reef structure over time. Reducing pollution, the influence of run-off, drainage of highlands and wetlands, and other sources of non-point pollution and land development in coastal areas can thus help to preserve the ecology and ecosystem services provided by coral reefs. 
Acknowledgements. The present research received financial support from the Wildlife Conservation Society (WCS) (T.R.M.) and Fundação para a Ciência e a Tecnologia, Portugal, and European Social Fund under the III Community Support Board (M.C.S.; SFRH/BD/789/2000 and SFRH/ $\mathrm{BPD} / 34634 / 2007$ ). We are grateful to J. Mariara and J. Maina for their assistance in collecting samples and $\mathrm{S}$. Mwangi of Kenya Marine and Fisheries Research Institute and J. Maina for water chemistry analysis. C. Hicks helped with the canonical correspondence analysis. Permission to undertake the work was provided by Kenya's Office of the President and for sampling in the MNPs was provided by Kenya Wildlife Services.

\section{LITERATURE CITED}

Bak RPM (1990) Patterns of echinoid bioerosion in two Pacific coral reef lagoons. Mar Ecol Prog Ser 66:267-272

Birkeland C (1988) Second-order ecological effects of nutrient input into coral communities. Galaxea 7:91-100

Bruggemann JH, van Kessel AM, van Rooij JM, Breeman AM (1996) Bioerosion and sediment ingestion by the Caribbean parrotfish Scarus vetula and Sparisoma viride: implications of fish size, feeding mode and habitat use. Mar Ecol Prog Ser 134:59-71

Bucher DJ, Harriott VJ, Roberts LG (1998) Skeletal microdensity, porosity and bulk density of acroporid corals. J Exp Mar Biol Ecol 228:117-136

> Carreiro-Silva M, McClanahan TR (2001) Bioerosion and herbivory in Kenyan coral reefs: the role of protection from fishing. J Exp Mar Biol Ecol 262:133-153

Chazottes V, Le Campion-Alsumard T, Peyrot-Clausade M (1995) Bioerosion rates on coral reefs: interactions between macroborers, microborers and grazers (Moorea, French Polynesia). Palaeogeogr Palaeoclimatol Palaeoecol 113:189-198

Chazottes V, Le Campion-Alsumard T, Peyrot-Clausade M, Cuet P (2002) The effects of eutrophication-related alterations to coral reef communities on agents and rates of bioerosion (Reunion Island, Indian Ocean). Coral Reefs 21:375-390

> Cooper TF, Ridd PV, Ulstrup KE, Humphrey C, Slivkoff M, Fabricius KE (2008) Temporal dynamics in coral bioindicators for water quality on coastal coral reefs of the Great Barrier Reef. Mar Freshw Res 59:703-716

Cooper TF, Gilmour JP, Fabricius KE (2009) Bioindicators of changes in water quality on coral reefs: review and recommendations for monitoring programmes. Coral Reefs 28:589-606

> Dunne T (1979) Sediment yield and land use in tropical catchments. J Hydrol 42:281-300

Edinger EN, Limmon GV, Jompa J, Widjatmoko W, Heikoop J, Risk M (2000) Normal coral growth rates on dying reefs: are coral growth rates good indicators of reef health? Mar Pollut Bull 40:404-425

Fabricius KE (2005) Effects of terrestrial runoff on the ecology of corals and coral reefs: review and synthesis. Mar Pollut Bull 50:125-146

Fleitmann D, Dunbar RB, McCulloch M, Mudelsee M, Vuille M, McClanahan TR, Cole JC, Eggins S (2007) East African soil erosion recorded in a 300 year old coral colony from Kenya. Geophys Res Lett 34:L04401 doi:10. 1029/2006GL028525

Fonseca AC, Dean HK, Cortés J (2006) Non-colonial coral macro-borers as indicators of coral reef status in the south Pacific of Costa Rica. Rev Biol Trop 54:101-115

Glynn PW (1997) Bioerosion and coral growth: a dynamic balance. In: Birkland C (ed) Life and death of coral reefs. Chapman \& Hall, New York, NY, p 73-87

Hallock P (1988) The role of nutrient availability in bioerosion: consequences to carbonate buildups. Palaeogeogr Palaeoclimatol Palaeoecol 63:275-291

Hallock P, Schlager W (1986) Nutrient excess and the demise of reefs and carbonate platforms. Palaios 1: 389-398

> Holmes KE (2000) Effects of eutrophication on bioeroding sponge communities with the description of new West Indian sponges, Cliona spp. (Porifera: Hadromerida: Clionidae). Invertebr Biol 119:125-138

Holmes KE, Edinger EN, Hariyadi, Limmon GV, Risk MJ (2000) Bioerosion of live massive corals and branching coral rubble on Indonesian coral reefs. Mar Pollut Bull 40:606-617

> Hughes TR, Rodrigues MJ, Bellwood DR, Ceccarelli D and others (2007) Phase shifts, herbivory, and the resilience of coral reefs to climate change. Curr Biol 17:360-365

> Hutchings P, Kiene WE, Cunningham RB, Donnelly C (1992) Spatial and temporal patterns of non-colonial boring organisms (polychaetes, sipunculans and bivalve molluscs) in Porites at Lizard Island, Great Barrier Reef. Coral Reefs 11:23-31

> Hutchings P, Peyrot-Clausade M, Osorno A (2005) Influence of land runoff on rates and agents of bioerosion of coral substrates. Mar Pollut Bull 51:438-447

Kiene WE, Hutchings PA (1992) Long-term bioerosion of experimental coral substrates from Lizard Island, Great Barrier Reef. Proc 7th Int Coral Reef Symp, Guam 1: 397-403

Kiene WE, Hutchings PA (1994) Bioerosion experiments at Lizard Island, Great Barrier Reef. Coral Reefs 13:91-98

> Lapointe BE, Barile PJ, Matzie WR (2004) Anthropogenic nutrient enrichment of seagrass and coral reef communities in the Lower Keys: discrimination of local versus regional nitrogen sources. J Exp Mar Biol Ecol 308:23-58

> Le Grand HM, Fabricius KE (2011) Relationship of internal macrobioeroder densities in living massive Porites to turbidity and chlorophyll on the Australian Great Barrier Reef. Coral Reefs 30:97-107

Lescinsky HL (2004) Bioerosion in the Caribbean: using coral bleaching as a natural experiment. Proc 11th Symp Geology of the Bahamas and other Carbonate Regions, San Salvador, p 25-34

Lescinsky HL, Hill M, Hoedt BA (2008) Results of long-term bioerosion study: Belize patch reefs. Proc 11th Int Coral Reef Symp, Florida 1:26-30

Littell RC, Milliken GA, Stroup WW, Wolfinger RD (2006) SAS ${ }^{\circledR}$ for mixed models, 2nd edn. SAS Institute, Cary, NC

McClanahan TR (1988) Seasonality in East Africa's coastal waters. Mar Ecol Prog Ser 44:191-199

McClanahan TR (2002) The near future of coral reefs. Environ Conserv 29:460-483

McClanahan TR, Arthur R (2001) The effect of marine reserves and habitat on populations of East African coral reef fishes. Ecol Appl 11:559-569

McClanahan TR, Kaunda-Arara J (1996) Fishery recovery in a coral reef marine park and its effect on the adjacent fishery. Conserv Biol 10:1187-1199

McClanahan TR, Shafir SH (1990) Causes and consequences of sea-urchin abundance and diversity in 
Kenyan coral reef lagoons. Oecologia 83:362-370

McClanahan TR, Hendrick V, Rodrigues MJ, Polunin NVC (1999) Varying responses of herbivorous and invertebrate-feeding fishes to macroalgal reduction on a coral reef. Coral Reefs 18:195-203

McClanahan TR, Muthiga NA, Mangi S (2001) Coral reef and algal changes after the 1998 coral bleaching: interaction with reef management and herbivores on Kenyan reefs. Coral Reefs 19:380-391

McClanahan TR, Maina J, Moothien-Pillay R, Baker AC (2005) Effects of geography, taxa, water flow, and temperature variation on coral bleaching intensity in Mauritius. Mar Ecol Prog Ser 298:131-142

Musso BM (1992) Rates of skeletal degradation following death in three species of Acropora. In: Richmond RH (ed) Proc 7th Int Coral Reef Symp, Guam 1:413-418

O'Leary JK, McClanahan TR (2010) Trophic cascades result in large-scale coralline algae loss through differential grazer effects. Ecology 91:3584-3597

Obura DO, Muthiga NA, Watson M (2000) Kenya. In: McClanahan TR, Sheppard CRC, Obura DO (eds) Coral reefs of the Indian Ocean: their ecology and conservation. Oxford University Press, Oxford, p 199-230

Osorno A, Peyrot-Clausade M, Hutchings PA (2005) Patterns and rates of erosion in dead Porites across the Great Barrier Reef (Australia) after 2 and 4 years of exposure. Coral Reefs 24:292-303

> Pari N, Peyrot-Clausade M, Le Campion-Alsumard T, Hutchings PA and others (1998) Bioerosion of experimental substrates in high islands and on atoll lagoons (French Polynesia) after two years of exposure. Mar Ecol Prog Ser 166:119-130

Parsons TR, Maita Y, Lalli CM (1984) A manual of chemical and biological methods for seawater analysis. Pergamon Press, New York, NY

Perry CT (1998) Macroborers within coral framework at Discovery Bay, north Jamaica: species distribution and abundance, and effects on coral preservation. Coral Reefs 17:277-287

Peyrot-Clausade M, Le Campion-Alsumard T, Hutchings $\mathrm{P}$, Le Campion J, Payri C, Fontaine MC (1995) Initial bioerosion and bioaccretion on experimental substrates in high island and atoll lagoons (French Polynesia). Acta Oecol 18:531-541

Reaka-Kudla ML, Feingold JS, Glynn W (1996) Experimental studies of rapid bioerosion of coral reefs in the Galapagos Islands. Coral Reefs 15:101-109

Risk MJ (1972) Fish diversity on a coral reef in the Virgin Islands. Atoll Res Bull 153:1-4

Risk MJ, McGeachy JK (1978) Aspects of bioerosion of modern Caribbean reefs. Rev Biol Trop 26(Suppl 1):85-105

Risk MJ, Sammarco PW, Edinger EN (1995) Bioerosion in Acropora across the continental shelf of the Great Barrier Reef. Coral Reefs 14:79-86

Risk MJ, Heikoop JM, Edinger EN, Erdmann MV (2001) The assessment 'toolbox': Community-based reef evaluation methods coupled with geochemical techniques to identify sources of stress. Bull Mar Sci 69:443-458

Rose CS, Risk MJ (1985) Increase in Cliona delitrix infestation of Montastrea cavernosa heads on an organically polluted portion of the Grand Cayman fringing reef. PSZN: I Mar Ecol 6:345-363

Sall L, Lehman A (1996) JMP start statistics. Duxbury Press, Belmont, MA

Sammarco PW, Risk MJ (1990) Large-scale patterns in internal bioerosion of Porites: cross continental shelf trends on the Great Barrier Reef. Mar Ecol Prog Ser 59:145-156

> Sammarco PW, Risk MJ, Rose C (1987) Effects of grazing and damselfish territoriality on internal bioerosion of dead corals: indirect effects. J Exp Mar Biol Ecol 112: 185-199

SAS Institute (2004) User's manual, ver. 9.0. SAS Institute, Cary, NC

- Schönberg C, Wilkinson C (2001) Induced colonization of corals by a clionid bioeroding sponge. Coral Reefs 20: 69-76

Scott PJB, Cope M (1986) Tolo revisited: a resurvey of corals in Tolo Harbour and Channel six years and half a million people later. In: Morton B (ed) Proceedings of the Second International Marine Biology Workshop: the marine flora and fauna of Hong Kong and Southern China. Hong Kong University Press, p 1203-1220

Smith SV, Kimmerer WJ, Laws EA, Brock RE, Walsh TW (1981) Kaneohe Bay sewerage diversion experiment: perspectives on ecosystem responses to nutritional perturbations. Pac Sci 35:279-395

Sokal RR, Rohlf FJ (1995) Biometry, 3rd edn. Freeman, San Francisco, CA

ter Braak CJF, Verdonschot PFM (1995) Canonical correspondence analysis and related multivariate methods in aquatic ecology. Aquat Sci 57:255-289

Tribollet A (2008) The boring microflora in modern coral reef ecosystems: a review of its roles. In: Wissak M, Tapanila L (eds) Current developments in bioerosion. Springer, Berlin, p 67-94

- Tribollet A, Golubic S (2005) Cross-shelf differences in the pattern and pace of bioerosion of experimental carbonate substrates exposed for 3 years on the northern Great Barrier Reef, Australia. Coral Reefs 24:422-434

Tribollet A, Golubic S (2011) Reef bioerosion: agents and processes. In: Dubinsky Z, Stambler N (eds) Coral reefs: an ecosystem in transition. Springer, Berlin, p 435-449

Tribollet A, Decherf G, Hutchings PA, Peyrot-Clausade M (2002) Large-scale spatial variability in bioerosion of experimental coral substrates on the Great Barrier Reef (Australia): importance of microborers. Coral Reefs 21: 424-432

Ward-Paige CA, Risk MJ, Sherwood OA, Jaap WC (2005) Clionid sponge surveys on the Florida Reef Tract suggest land-based nutrient inputs. Mar Pollut Bull 51:570-579 
Appendix 1. Bioerosion rates $\left(\mathrm{g} \mathrm{CaCO}_{3} \mathrm{~m}^{-2}\right.$, mean $\pm \mathrm{SE}$ ) by boring macroorganisms (sponges, bivalves, and worms) and by all macroboring agents combined of coral branches exposed for 4 and 6 yr in 8 coral reef lagoons in Kenya, Eastern Africa

\begin{tabular}{|c|c|c|c|c|c|c|c|c|}
\hline \multirow[t]{2}{*}{ Reefs } & \multicolumn{2}{|c|}{ Sponges } & \multicolumn{2}{|c|}{ Bivalves } & \multicolumn{2}{|c|}{ Worms } & \multicolumn{2}{|c|}{ Total } \\
\hline & $4 \mathrm{yr}$ & $6 \mathrm{yr}$ & $4 \mathrm{yr}$ & $6 \mathrm{yr}$ & $4 \mathrm{yr}$ & $6 \mathrm{yr}$ & $4 \mathrm{yr}$ & $6 \mathrm{yr}$ \\
\hline \multicolumn{9}{|c|}{ Unfished reefs (marine protected areas) } \\
\hline Malindi & $875 \pm 128$ & $983 \pm 160$ & $81 \pm 128$ & $82 \pm 40$ & $173 \pm 28$ & $337 \pm 55$ & $1135 \pm 118$ & $1402 \pm 163$ \\
\hline Watamu & $501 \pm 89$ & $1916 \pm 458$ & $42 \pm 42$ & $17 \pm 13$ & $242 \pm 24$ & $211 \pm 41$ & $785 \pm 96$ & $2149 \pm 439$ \\
\hline Mombasa & $644 \pm 141$ & $467 \pm 101$ & $63 \pm 43$ & $152 \pm 59$ & $183 \pm 38$ & $794 \pm 125$ & $896 \pm 155$ & $1413 \pm 137$ \\
\hline Kisite & $440 \pm 22$ & $438 \pm 94$ & $22 \pm 86$ & $161 \pm 112$ & $208 \pm 36$ & $465 \pm 89$ & $666 \pm 90$ & $1064 \pm 170$ \\
\hline \multicolumn{9}{|l|}{ Fished reefs } \\
\hline Ras Iwatine & $643 \pm 86$ & $779 \pm 221$ & $56 \pm 27$ & $54 \pm 32$ & $356 \pm 36$ & $698 \pm 95$ & $1084 \pm 111$ & $1516 \pm 277$ \\
\hline Mpunguti & $236 \pm 56$ & $297 \pm 102$ & $38 \pm 38$ & $169 \pm 122$ & $261 \pm 63$ & $371 \pm 56$ & $534 \pm 91$ & $837 \pm 156$ \\
\hline Kanamai & $382 \pm 95$ & $733 \pm 200$ & 0 & $93 \pm 62$ & $508 \pm 74$ & $734 \pm 120$ & $891 \pm 97$ & $1560 \pm 205$ \\
\hline Diani & $256 \pm 59$ & $577 \pm 148$ & $84 \pm 26$ & $39 \pm 24$ & $379 \pm 47$ & $412 \pm 60$ & $719 \pm 74$ & $1028 \pm 159$ \\
\hline
\end{tabular}

Editorial responsibility: Charles Birkeland, Honolulu, Hawaii, USA
Submitted: November 1, 2011; Accepted: March 15, 2012 Proofs received from author(s): June 13, 2012 